\title{
Microstructures associated with the Sottunga-Jurmo shear zone and their implications for the 1.83-1.79 Ga tectonic development of SW Finland
}

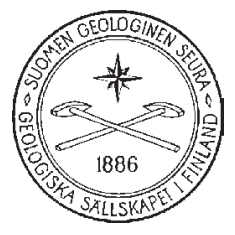

Tajja Torvela ${ }^{1,2) *}$ and Carl Ehlers ${ }^{1)}$

1) Abo Akademi University, Department of geology and mineralogy, Tuomiokirkontori 1, FI-20500 Turku, Finland

2) Present address: University of Aberdeen, Department of geology and petroleum geology, Meston Building, King's College, Aberdeen AB24 3UE, Scotland, UK

\begin{abstract}
This petrographic study of rock samples from the area of a large-scale shear zone, the Sottung-Jurmo shear zone, in SW Finland, illuminates the thermal development of and strain distribution within the rocks during the last development stages of the shear zone. The results indicate relatively high temperatures during the deformation phases that created the gneisses and the mylonites, strain partitioning through time and continued transpression from S-SW until at least c. $1.79 \mathrm{Ga}$. This has implications to the latest tectonic models since the results together with previous studies suggest a compartmentalisation of regional stresses between the area SW of the shear zone and central Fennoscandia. The results also suggest that the uplift rate increased during the late stage of the transpression.
\end{abstract}

Key words: shear zones, gneisses, mylonites, pseudotachylite, cataclasites, deformation, tectonics, Paleoproterozoic, Sottunga, Jurmo, Åland, Finland

*Corresponding author email: taija.torvela@abdn.ac.uk

\section{Introduction}

The Fennoscandian shield is an amalgam of crustal domains that cover a time span of over $2400 \mathrm{Ma}$ from the Archaean to the Caledonian (Fig. 1; e.g. Gaál \& Gorbatschev, 1987; Nironen, 1997; Lahtinen et al., 2005). The Palaeoproterozoic Fennoscandian domain comprises large parts of Sweden, Finland and the Estonian basement as well as mi- nor parts of Norway and Russian Karelia. Many of these domains (domains A-D and the PAC, CSAC and SSAC in Fig. 1) formed during a prolonged and complex tectonic history between c. 2.0-1.78 Ga that is often referred to as the Svecofennian orogeny (e.g. Gaál \& Gorbatschev, 1987; Nironen, 1997). Recently, the Svecofennian orogeny has been 


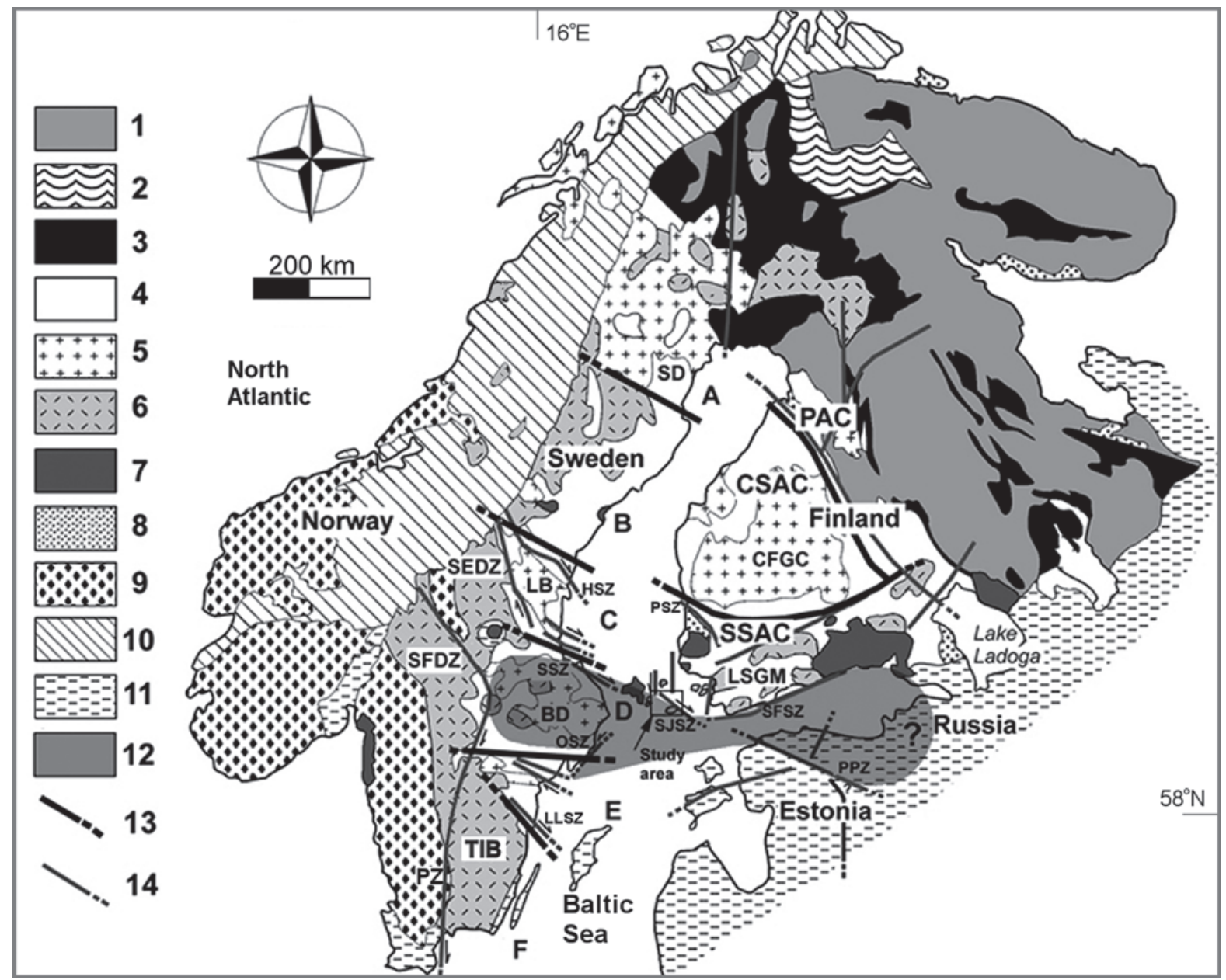

Fig. 1. Generalised geological map of the Fennoscandian shield. Key: 1 Archaean rocks 3.2-2.5 Ga; 2 Lapland granulite belt 2.2-1.9 Ga; 3 Karelian supracrustal rocks 2.5-1.9 Ga; 4 Svecofennian supracrustal rocks 2.0-1.85 Ga; 5 (Sveco)Fennian pre- and synorogenic magmatic rocks 1.95-1.85 Ga; 6 Svecobaltic and Nordic granites and migmatites (previously called late-Svecofennian) 1.85-1.77 Ga; 7 Anorogenic rapakivi granites 1.65-1.4 Ga; 8 Sandstones, Jotnian and younger 1.5-0.57 Ga; 9 Palaeoproterozoic to Sveconorwegian (1.25-0.9 Ga) rocks; 10 Caledonian rocks 0.6-0.4 Ga; 11 Phanerozoic sedimentary cover <0.57 Ga; 12 Mainly amphibolite facies terranes; 13 Domain borders; 14 Major Palaeoproterozoic deformation zones of the bedrock; LSGM = Late Svecofennian Granite Migmatite zone; PAC = Primitive Arc Complex of central Finland; CSAC = Central Svecofennian Arc Complex; SSAC = Southern Svecofennian Arc Complex; CFGC = Central Finland Granitoid Complex; LB = Ljusdal batholith; BD = Bergslagen district; SD = Skellefte district; TIB = Trans-Scandinavian Igneous Belt A-F = Palaeoproterozoic and Archaean bedrock domains in Sweden (partly from Sjöström \& Bergman, 1998); SFSZ =South Finland shear zone; SJSZ = Sottunga-Jurmo shear zone; PSZ = Pori shear zone; PPZ = Paldiski-Pskov shear zone; HSZ = Hassela shear zone; SEDZ = Storsjön-Edsbyn deformation zone; SSZ = Singö shear zone; OSZ = Ornö shear zone; LLSZ = Loftahammar-Linköping shear zone; SFDZ = Sveconorwegian Frontal deformation zone; PZ = Protogine Zone. Modified from a map compiled from Korsman et al. (1997) by Fredrik Strandman, Åbo Akademi.

divided into the Fennian orogeny at c. 1.89-1.87 $\mathrm{Ga}$, the Svecobaltic orogeny at 1.84-1.80 Ga and the Nordic orogeny at 1.82-1.79 Ga, each of which accreted the older domains to each other and added juvenile crustal material so that the bulk of the
Fennoscandian Shield was largely cratonised at 1.79-1.78 Ga (Lahtinen et al., 2005).

The bedrock in southern Finland represents the mid- to lower mid-crustal levels of mostly Fennian orogenic roots and show P-T conditions and clock- 
wise P-T-t paths typical for convergent orogenies (e.g. Väisänen \& Hölttä, 1999; Kurhila et al., 2005). From c. 1.85-1.84 Ga onwards, much of the regional deformation partitioned into regional folds and ductile crustal-scale shear zones throughout the Fennoscandian shield (e.g. Ehlers \& Lindroos, 1990; Kärki et al., 1993; Sjöström \& Bergman, 1998; Högdahl, 2000; Väisänen, 2002; Soesoo et al., 2004). Some of these shear zones follow crustal discontinuities that have been interpreted as terrane boundaries (e.g. 'Pori shear zone', Hassela shear zone, Singö shear zone; Fig. 1; e.g. Gaál \& Gorbatschev, 1987; Sjöström \& Bergman, 1998; Högdahl et al., 2009). Another such a postulated boundary is a several kilometres wide shear structure, the Sottunga-Jurmo shear zone (SJSZ) that extends in a NWSE direction through the Åland and Turku archipelagos (Torvela \& Ehlers, 2010; Figs. 1, 2). The area of this study comprises the municipality of Sottunga as well as large parts of the municipality of Kökar in the Åland archipelago in SW Finland (Fig. 2). The SJSZ is exceptionally well exposed on the ice-polished shores of the hundreds of islands and

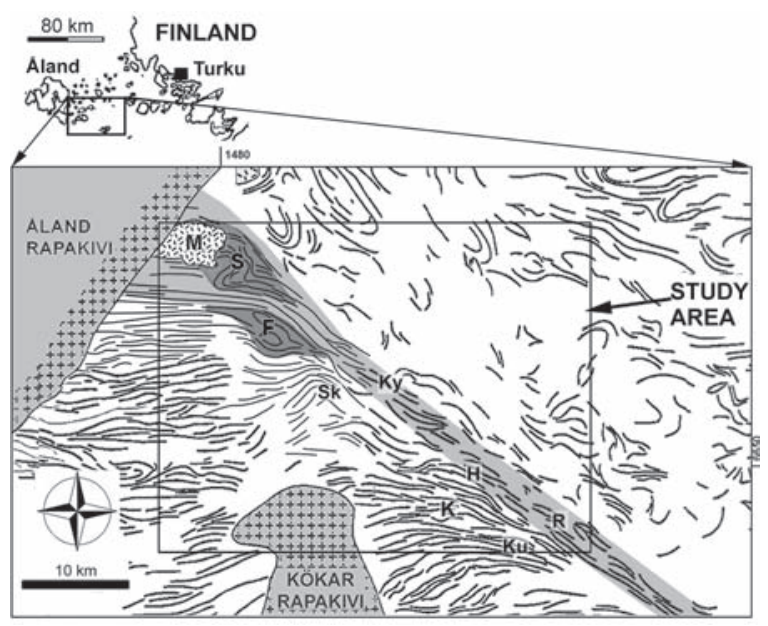

Fig. 2. Foliation map of Åland archipelago (modified from Ehlers \& Lindroos, 1990). The location of the main, pervasively sheared SJSZ is marked with light grey and the Finnö and Sottunga tectonic lenses with dark grey (see text). The overall dextral kinematics of the ductile shearing is evidenced by the deflected foliations in the NW part and SW of the zone. Areas: Ku = Östra Kuggskär, R = Norra Rödskär, K = Kökar, H = Hellsö, Sk = Skattskär, Ky = Kyrkogårdsö, $\mathbf{F}=$ Finnö, $\mathbf{S}=$ Sottunga, $\mathbf{M}=$ Mosshaga pluton. Map coordinates in KKJ. skerries of the archipelago. It is therefore possible to follow the changes in the deformation style, strain intensity and the orientation of the deformation fabrics from areas south of the main shear zone northwards into the zone of the highest strain, as well along the SJSZ.

The main goal of this contribution is to describe the petrographic observations from the SJSZ area and to discuss the implications of the findings to the development of the bedrock in southwestern Finland.

\section{Geological setting}

The Svecofennian domain is a complex tectonic unit created by multi-stage accretionary and collosional orogenic events by which at least two newly formed arc complexes collided with each other and with the Archaean craton. The main direction of convergence was approximately towards NE during the first, Fennian orogeny (in central Finland; e.g. Gaál \& Gorbatschev, 1987; Nironen, 1997; Väisänen, 2002). The Fennian orogeny was followed by the Andean-type Svecobaltic orogeny at c. 1.84-1.80 Ga with transpression from S-SSE, during which the supracrustal belts in SW Finland and central Sweden were offset by crustal-scale shear systems (Fig. 1; e.g. Ehlers et al., 1993; Lahtinen et al., 2005, and references therein; Levin et al., 2005). The last Palaeoproterozoic compressive event that significantly affected the Fennoscandian Shield was the continent-continent collision -type Nordic orogeny at 1.82-1.79 Ga with subduction from the NWWNW (Fig. 3). The Nordic orogeny closed the ocean between the Fennoscandian shield and the Amazonia and resulted in large-scale granite and syenitoid magmatism in the western of the shield (TIB in Fig. 1). Simultaneously, docking of Sarmatia occurred in the southeast, and an unknown microcontinent probably also converged from south and collided with the present southern Finland-central Sweden (approx. domain F in Fig. 1; Lahtinen et al., 2005, and references therein). Lahtinen et al., (2005) suggest a period of extension and orogenic collapse at 1.80-1.77 Ga in southern Finland at the late stages of and following the Nordic orogeny. 


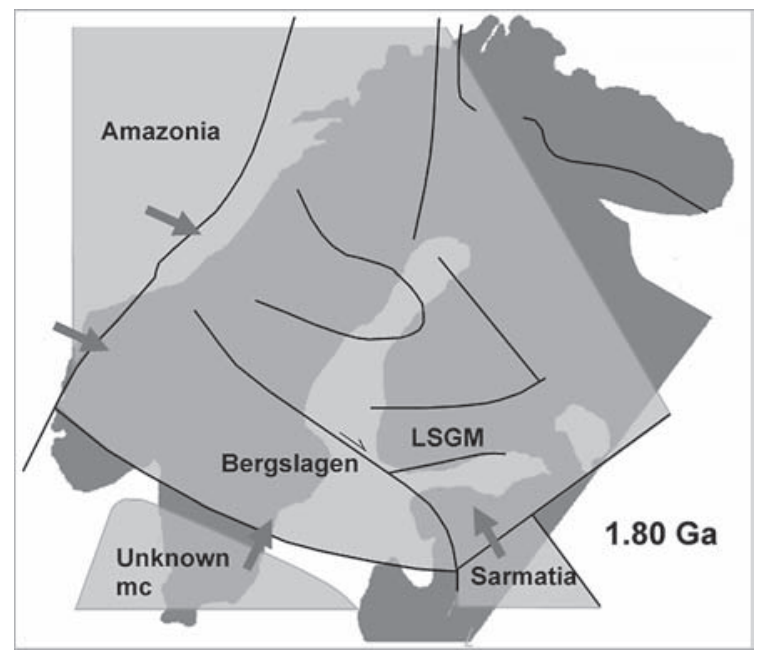

Fig. 3. A schematic tectonic model for the Fennoscandian shield during the late stage of the Nordic orogeny $(\sim 1.80$ Ga) according to Lahtinen et al. (2005). LSGM = Late Svecofennian Granite Migmatite zone. Figure modified from Lahtinen et al. (2005).

The Sottunga-Jurmo shear zone (SJSZ) was first recognised by Ehlers \& Ehlers (1977), Edelman \& Jaanus-Järkkälä (1983), Branigan (1987) and Hubbard \& Branigan (1987), all of whom also noted the presence of other, N-S as well as NE-SW striking ductile and brittle fault structures in the Alland archipelago. All of the ductile shear zones in the area, including the SJSZ, may have formed approximately simultaneously as a conjugate set or sets. The (semi)brittle fault zones in the area likely formed due to late reactivations of some of the older ductile zones. However, neither the ductile nor the brittle zones other than the SJSZ have yet been studied sufficiently to make any definite conclusions of their role in the structural development of the area and are, therefore, not discussed further.

Different definitions have been proposed in earlier papers for the shear zones in southern Finland: Ehlers et al. (2004) propose that the SJSZ changes direction near the island of Jurmo, SE of Aland, and continues eastwards toward and along the southern coast of Finland, then curving gradually toward east-northeast so that the entire structure is more than $200 \mathrm{~km}$ long (Fig. 1). They propose the name South Finland Shear Zone (SFSZ) for this major shear structure. The SFSZ is here suggested to only apply for the shear structure that extends along the southern Finnish coast (from east of Jurmo eastwards; not included in this study; Figs. 1 and 4). The SFSZ is still insufficiently studied, and its connection to the SJSZ is unclear. The structural observations and conclusions from the SJSZ presented in this paper cannot therefore be claimed to represent the SFSZ.

The post-orogenic, -1788 Ma Mosshaga pluton (Welin et al., 1983) is emplaced within the shear zone in the NW, and both the pluton and the shear zone are transected by the anorogenic, $\sim 1.58-1.57$ Ga Åland rapakivi granite batholith (Suominen, 1991; Figs. 2, 4). From the Kökar area, the shear zone continues toward the SE and the island of Jurmo in the SW Turku archipelago. The SJSZ has a spatial and temporal connection to several shear zones in the NW (east-central Sweden) such as SSZ and HSZ (Fig. 1; e.g. Sjöström \& Bergman, 1998; Högdahl, 2000; Högdahl et al., 2009). The continuation toward the E-SE is covered by the Baltic Sea, but the magnetic anomaly map (Korhonen et al., 2002) implies that the SJSZ and the NW-SE trending major shear structure in the Precambrian basement of Estonia, the Paldiski-Pskov Shear Zone, are related (PPZ; Fig. 1). Soesoo et al. (2004) suggest that the PPZ in Estonia is a direct continuation of the shear zone in Alland, referring to the entire structure as the Alland-Paldiski-Pskov Shear Zone. Lahtinen et al. (2005) conclude that a continuous shear zone that is essentially a transform fault, also representing a terrane boundary, extends from central Sweden (HSZ) to Estonia, where it turns towards the south (Fig. 3). According to their interpretation, the SJSZ would be a part of this largescale transform fault. Also Korja \& Heikkinen (2005) suggest that a terrane boundary exists from central Sweden to Estonia. Recent studies by Högdahl et al. (2009) and Torvela \& Ehlers (2010) support the interpretation of a terrane boundary in this area. Torvela \& Ehlers (2010) further suggest that the SJSZ, as a part of this terrane boundary, compartmentalised the orogenic stresses in south-central Fennoscandia around 1.79 Ga.

The main structural development of the SJSZ is relatively well established (Ehlers \& Lindroos, 1990; Torvela, 2007; Torvela \& Ehlers, 2010). The 

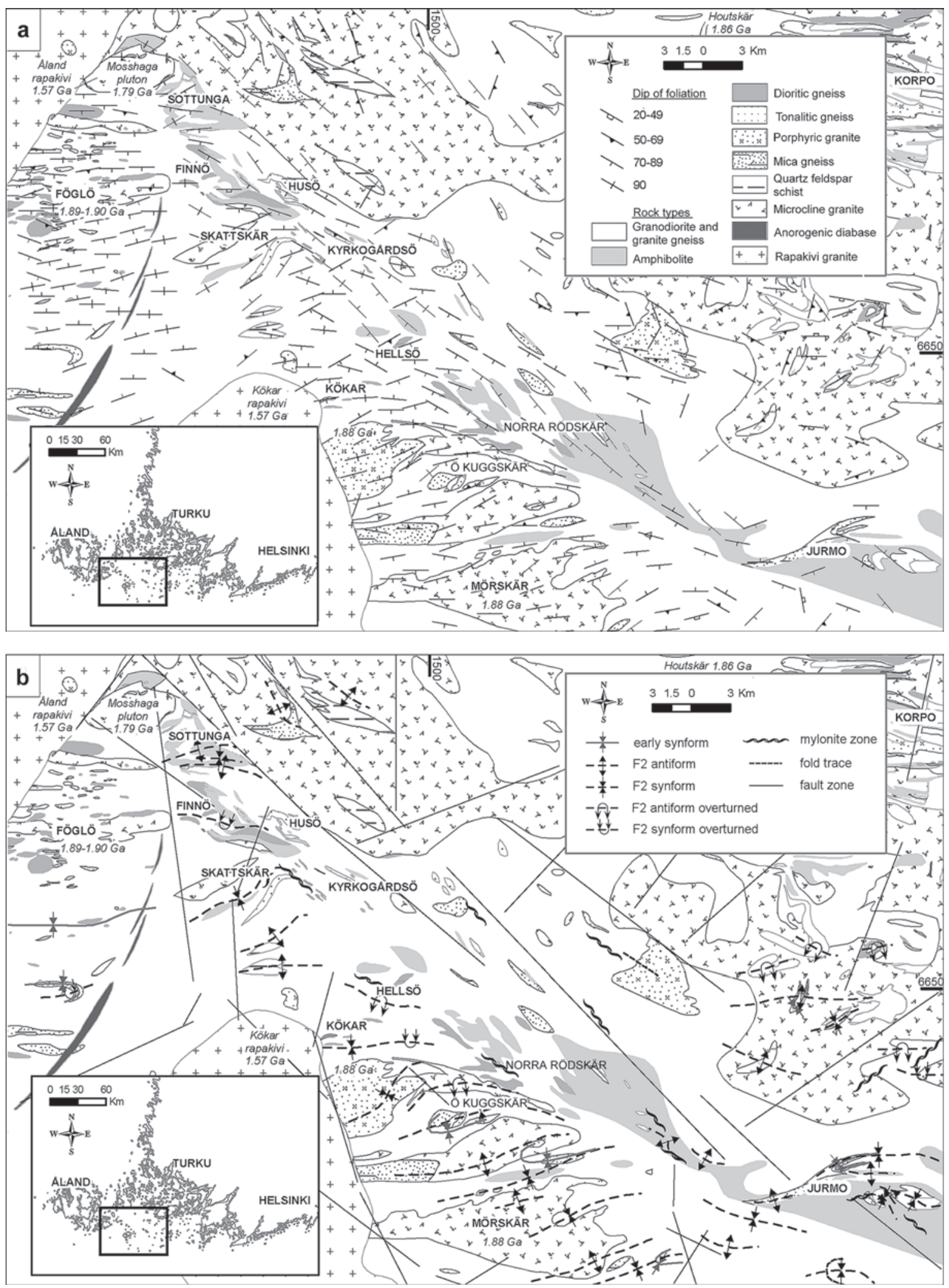

Fig. 4. Geological overview maps of the Åland archipelago; a) Representative foliations; b) Representative fold axial traces, mylonite zones and major (brittle) fault zones. Modified from Torvela \& Ehlers (2010). Coordinates in KKJ. 
SJSZ shows dextral overall kinematics with a SWside up vertical component and an apparent minimum offset in the order of some tens of kilometres. The minimum offset is a very rough estimate based on the deflection of the foliations in the gneisses SW of the shear zone (Fig. 2); the total amount of offset is probably larger but is very difficult to quantify due to the high strains and the multi-stage development history of the shear zone. The kinematic interpretation is based on the deflection of the large-scale fold axial traces and foliations south of the shear zone (Ehlers \& Lindroos, 1990), on field observations (Torvela, 2007; Torvela \& Ehlers, 2010) and on microstructural observations (this paper).

To the NE of the SJSZ, the rocks differ in structure, lithology and metamorphic grade from to the rocks to the SW of the shear zone. To the NE, a c. $200 \mathrm{~km}$ wide belt (the Late-Svecofennian GraniteMigmatite belt, LSGM in Fig. 1; Ehlers et al., 1993) extends across southern Finland. The LSGM rocks consist of structurally overturned and tectonically stacked supracrustal rocks, metamorphosed in up to granulite facies conditions (e.g. Ehlers et al., 1993; Väisänen \& Hölttä, 1999). The LSGM rocks are extensively migmatised and intruded by subhorizontal sheets of anatectic granites and tonalites at 1.85-1.82 Ga (e.g. Johannes et al., 2003; Kurhila et al., 2005; Stålfors \& Ehlers, 2005). In contrast to the LSGM, the SJSZ and the area to the SW consist mainly of amphibolite facies orthogneisses dominated by steep foliations and fold axial surfaces (Fig. 4). The extensive $-1.85-1.82 \mathrm{Ga}$ anatectic granite magmatism and associated migmatisation common within the LSGM has not occurred in the study area. Instead, $\sim 1.79$ Ga granitic intrusions and associated small-scale granitic veins and dykes are quite common (e.g. Suominen, 1991; Ehlers et al., 2004). A U-Pb titanite age of $\sim 1.79 \mathrm{Ga}$ in a granodioritic gneiss has also been recorded at the shear zone margin on Hellsö (Ehlers et al., 2004). The relationship between the LGSM and the SJSZ (and SFSZ) remains somewhat uncertain, although an obvious spatial connection can be observed as both the SJSZ and the SFSZ closely follow the southern margin of the LSGM. Stallfors \& Ehlers (2005) suggest that the emplacement and fractionation of the
- 1.83 Ga LSGM granitic melts in Nagu (c. 40 km to NE from Kökar) was a shear-assisted processes, and propose a model where subvertical crustal-scale shear zones functioned as transport channels for the magmas. Such processes, however, seem to be absent within and to the south of the SJSZ; on the other hand, the northern margin of the SJSZ is not well exposed.

The peak P-T conditions of shear deformation $(-1.83 \mathrm{Ga})$ within the SJSZ have been calculated to $600-700^{\circ} \mathrm{C}$ and 6.4-7.1 kbar, i.e. upper amphibolite facies conditions (garnet-biotite ( $\mathrm{Gt}-\mathrm{Bt}$ ) geothermometry and garnet-plagioclase-biotite-quartz (GPBQ) geobarometry; Torvela \& Annersten, 2005; Torvela, 2007). The approximately coeval LSGM metamorphism occurred at high- $\mathrm{T}$, low-P granulite facies conditions at up to c. $800-825^{\circ} \mathrm{C}$ and 6.3-6.7 kbar, although the peak pressures usually are around 5-6 kbar (Gt-Bt/Gt-Crd geothermometry and Gt-Crd-Sill-Qtz geobarometry; e.g. Väisänen \& Hölttä, 1999; Johannes et al., 2003). It should be noted in this context that the major ductile shear zones in central Sweden separate the domains $\mathrm{C}$ and $\mathrm{D}$ as well as domains $\mathrm{D}$ and E (Fig. 1), domain $\mathrm{D}$ being of a lower metamorphic grade (mostly amphibolite facies) than domains $\mathrm{C}$ and $\mathrm{E}$ (Sjöström \& Bergman, 1998). This is consistent with the metamorphic conditions across the SJSZ as the rocks to the south of the shear zone are mostly amphibolite facies rocks, as opposed to the amphibolite-to-granulite facies LSGM. Furthermore, the major shear structure cutting through the Estonian basement (PPZ; Fig. 1) also separates a dominantly granulite facies terrane to the south and an amphibolite facies terrane to the north (Soesoo et al., 2004). Therefore, there seems to be a relatively continuous belt of a lower metamorphic grade south of the high-T, low-P amphibolite-to-granulite facies terranes of the LSGM in Finland and domain C in Sweden (Fig. 1). The SJSZ offsets the amphibolite facies belt dextrally.

The SJSZ has been repeatedly activated, starting with ductile gneissose deformation that is locally followed, in places possibly overprinted, by higher-strain, ductile to semi-ductile deformation producing mylonite zones of variable widths. A late 
stage of activity along the shear zone is recorded by brittle fault rocks (pseudotachylytes and cataclasites). The time frame for the polyphase deformation within the SJSZ has been quite well established (Suominen, 1991; Ehlers et al., 2004; Torvela et al., 2008). The rocks within the area show magmatic ages of -1.88-1.89 Ga (Suominen, 1991; Ehlers et al., 2004; Torvela et al., 2008). These are typical ages for intrusive early Svecofennian granitoids and, within the LSGM, for their volcanic counterparts throughout southern Finland (e.g. Patchett $\&$ Kouvo, 1986; Väisänen \& Mänttäri, 2002). The first recorded ductile deformation phase within the present SJSZ, possibly with shearing, existed at -1.85 $\mathrm{Ga}$. By the second deformation phase at $-1.83 \mathrm{Ga}$ the shear zone was already well developed (U-Pb ages from metamorphic zircon rims and metamorphic titanites; Torvela et al., 2008). The last reactivation of the shear zone within the ductile regime took place at $-1.79 \mathrm{Ga}$, after which the rocks rapidly cooled and entered the brittle-ductile transition zone (U-Pb age from metamorphic titanites; Torvela et al., 2008; this paper).

The SJSZ was reactivated at least once at strain rates high enough to produce cataclasites and pseudotachylytes that formed in several places along the shear zone. The pseudotachylytes may be related to the intrusion of the $-1.57 \mathrm{Ga}$ anorogenic rapakivi granite plutons close to the study area as ${ }^{40} \mathrm{Ar} /{ }^{39} \mathrm{Ar}$ dating of some of the pseudotachylytes indicate a minimum age, although somewhat ambiguous, of $-1.58 \mathrm{Ga}$ (Torvela et al., 2008). However, the microstructural observations presented in this paper imply that at least some of the pseudotachylytes may have formed at relatively deep crustal levels, i.e. not (entirely) within the brittle regime. The maximum age for the pseudotachylytes is $\sim 1.78 \mathrm{Ga}$ based on the magmatic $\mathrm{U}-\mathrm{Pb}$ zircon age for granite pegmatite dykes that are offset by the pseudotachylytes (Torvela et al., 2008).

\section{Microstructures}

In the following sections, we summarise the petrographic observations made from thin sections prepared from rock samples from the SJSZ area. We follow the microstructural terminology presented in Passchier \& Trouw (2005). The thin sections are cut parallel to lineation (where observable) and perpendicular to foliation.

\section{Gneisses}

The mineralogy and the texture of the gneissose rocks within and SW of the SJSZ reflect their nature as mainly quartzo-feldspatic, relatively high-grade gneisses with mainly igneous origins (Table 1). The gneissose foliation in quartz-rich (granitic and

Table 1. Summary of the different rock types in the Kökar and Sottunga areas.

\begin{tabular}{|c|c|c|c|c|c|c|}
\hline Rock type & $\begin{array}{l}\text { Gneisses } \\
\text { Felsic }\end{array}$ & Intermediate & Mafic & $\begin{array}{l}\text { Mylonites } \\
\text { Proto-/mesomylonite }\end{array}$ & Ultramylonite & Pseudotachylyte \\
\hline Occurrence & Dominating & Very common & Locally common & Locally common & Locally occurring & Rare \\
\hline Mineralogy & $\begin{array}{l}\text { Qtz, Pl, Kfs, Bt } \pm \\
\text { Ms } \pm \text { Hbl; acc. Ep, } \\
\text { Ap, Chl (rare), Ttn } \\
\text { (rare), Rt (rare), Grt } \\
\text { (rare) }\end{array}$ & $\begin{array}{l}\mathrm{Pl}, \mathrm{Hbl}, \mathrm{Qtz} \pm \mathrm{Ttn} \\
\text { (common) } \pm \mathrm{Bt} \pm \mathrm{Kfs} \\
\text { (rare); acc. Ep, Ap, } \\
\text { Rt, Chl (rare), Grt } \\
\text { (rare) }\end{array}$ & $\begin{array}{l}\mathrm{Hbl}, \mathrm{Pl}, \mathrm{Bt}, \mathrm{Opq} \text {; } \\
\text { rarely Cpx, Ol } \\
\text { with alteration } \\
\text { products Ur, Idd, } \\
\text { Chl, Mag }\end{array}$ & $\begin{array}{l}\text { Depending on the } \\
\text { mineralogy of the } \\
\text { original rock; either } \\
\text { Hbl-Pl rich or } \\
\text { Kfs-Pl rich }\end{array}$ & $\begin{array}{l}\text { Depending on the } \\
\text { mineralogy of the } \\
\text { original rock; } \\
\text { either Hbl-Pl rich } \\
\text { or Kfs-Pl rich }\end{array}$ & $\begin{array}{l}\text { Pl microlites } \\
\text { sometimes } \\
\text { discernible in } \\
\text { the microscope }\end{array}$ \\
\hline Texture & $\begin{array}{l}\text { Medium grained, } \\
\text { granoblastic to } \\
\text { semi-schistose, } \\
\text { occasionally } \\
\text { porphyritic }\end{array}$ & $\begin{array}{l}\text { Medium grained, } \\
\text { granoblastic to } \\
\text { semi-schistose, } \\
\text { rarely porphyritic }\end{array}$ & $\begin{array}{l}\text { Medium to coarse } \\
\text { grained, mostly } \\
\text { granoblastic }\end{array}$ & $\begin{array}{l}\text { Mylonitic: } \\
\text { porphyroclasts in } \\
\text { fine-grained mica- } \\
\text { rich matrix (10- c. } \\
90 \%)\end{array}$ & $\begin{array}{l}\text { Mylonitic: } \\
\text { porphyroclasts in } \\
\text { fine grained to } \\
\text { aphanitic matrix } \\
\text { (> c. } 90 \%)\end{array}$ & $\begin{array}{l}\text { Aphanitic to } \\
\text { ophitic }\end{array}$ \\
\hline $\begin{array}{l}\text { Deformation } \\
\text { regime and } \\
\text { style(s) }\end{array}$ & Ductile; & Ductile; & $\begin{array}{l}\text { Ductile (little } \\
\text { deformation, } \\
\text { extensive meta- } \\
\text { somatic alteration) }\end{array}$ & Ductile; & $\begin{array}{l}\text { Ductile to semi- } \\
\text { ductile; }\end{array}$ & Semi-brittle \\
\hline
\end{tabular}

Abbreviations: $\mathrm{Ap}=$ apatite; $\mathrm{Bt}=$ biotite; $\mathrm{Chl}=$ chlorite; $\mathrm{Cpx}=$ clinopyroxene; $\mathrm{Ep}$ = epidote; Grt = garnet; $\mathrm{Hbl}=$ hornblende; Idd = iddingsite; $\mathrm{Kfs}=$ potassium feldspar; $\mathrm{Mag}$ = magnetite; $\mathrm{Ms}=$ muscovite; $\mathrm{Ol}=$ olivine; $\mathrm{Opq}=$ opaques; $\mathrm{Pl}=$ plagioclase; $\mathrm{Qtz}=$ quartz; $\mathrm{Rt}=$ rutile; $\mathrm{Ttn}=$ titanite; $\mathrm{Ur}=$ uralite. 
granodioritic) gneisses is commonly defined by mica (biotite), while in tonalitic and gabbroic gneisses the foliated fabric is mainly a result of the slightly elongate hornblende, with or without biotite. In all gneisses, the individual feldspar and quartz grains are normally relatively equigranular, but define bands and/or lenses between the biotite-rich layers. Where dynamic recrystallisation has been most intense and static recovery has not completely overprinted or destroyed the dynamic recrystallisation structures, the feldspars also occasionally display core-and-mantle structures where a fine-grained feldspar mantle has developed around a core of an old grain. Also feldspar-quartz myrmekites are locally common in the quartz-rich gneisses. In all of the gneissose rock samples there are at least lenses and layers where the minerals are internally relatively strain-free despite the evident strong deformation. However, especially when the main shear zone
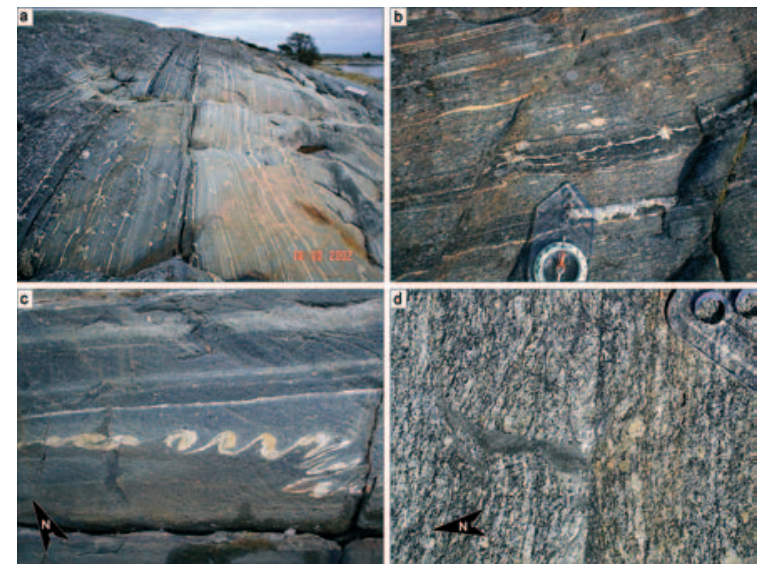

Fig. 5. Different deformation styles within the study area. The length of the compass c. $15 \mathrm{~cm}$; a) Ductilely deformed, medium-grained gneisses. A layer of amphiboliterich tonalite gneiss runs parallel with the granodioritic gneiss on both sides. The tonalitic layer is slightly boudinaged both horizontally and vertically (vertical stretch not visible). Storskär, Kyrkogårdsö area, view toward SE; b) Alkali feldspar-rich mesomylonite zone in a granodioritic gneiss (top centre of the figure), Skattskär, Kyrkogårdsö c) A detail of an alkali feldspar-rich ultramylonite with $\delta$-porphyroclasts and intense folding of the potassium feldspar rich layer showing dextral shear sense, Kyrkogårdsö, width of the photo $\mathrm{c} .7 \mathrm{~cm}$; d) Pseudotachylyte within a granodioritic gneiss protolith, Hellsö, Kökar, width of the photo c. $12 \mathrm{~cm}$. is approached, micro- and mesoscopic layers and bands where the mineral grains are more dynamically deformed become increasingly common, the grains retaining much of the internal strain of the last ductile deformation phase(s). Extensive retrograde (greenschist facies) reactions are mostly absent in the gneisses, indicating that the temperature decreased rather rapidly from transitional amphibolite/amphibolite-greenschist facies conditions, and/or fluid activity (or partial pressure) was not high enough to facilitate retrograde hydration reactions. However, there are exceptions, as it seems that locally some greenschist/amphibolite-greenschist facies metamorphism was enabled, suggesting that fluid channelling may have been of significant importance during or after the last deformation phase. The various microstructural features of the rock samples from different parts of the study area are further elaborated in the following sections.

The rocks outside the main SJSZ (western and southern Kökar) show distinctly different microstructures compared to the rocks at the margin of and within the main shear zone (Hellsö and Kyrkogårdsö areas, respectively; Figs. 2 and 4). Areas and layers with monomineralic quartz ribbons with relatively strain-free grains and polygonised grain boundaries are common ('foam structure' formed as a result of grain boundary area reduction, GBAR; e.g. Evans et al., 2001). However, slightly lobate grain boundaries, formed due to grain-boundary migration processes, remain in many places (GBM; e.g. Jessell, 1987; Stipp et al., 2002; Fig. 6a). The GBM processes also resulted in the reduction of intra-grain stresses as evidenced by the relatively 'strain-free' grains (Hirth \& Tullis, 1992; Stipp et al., 2002). The presence of slightly undulose quartz grains indicates that subgrain rotation recrystallisation (SGR) processes were active during the last deformation stage recorded by the studied samples (Hirth \& Tullis, 1992; Fig. 6a). In feldspars, myrmekites are abundant, commonly at grain boundaries sub-perpendicular to the direction of the maximum compressive stress (approximately $\mathrm{N}-\mathrm{S}$ directed), and undulose extinction occurs (Figs. 6b, c). Also 'core-and-mantle' structures, formed due to SGR and bulging recrystallisation (BLG), are fre- 
quently encountered (e.g. Tullis \& Yund, 1991; Gapais, 1989; Fig. 6c). In other places, the rocks seem completely statically recrystallised, resulting in an equigranular rock with strain-free grains (Fig. 6d).
At the shear zone margin, the dynamic recrystallisation structures are better preserved. Furthermore, the difference between the deformation behaviour of the quartz-rich vs. quartz-poor rocks becomes more obvious: the mafic rocks are com-
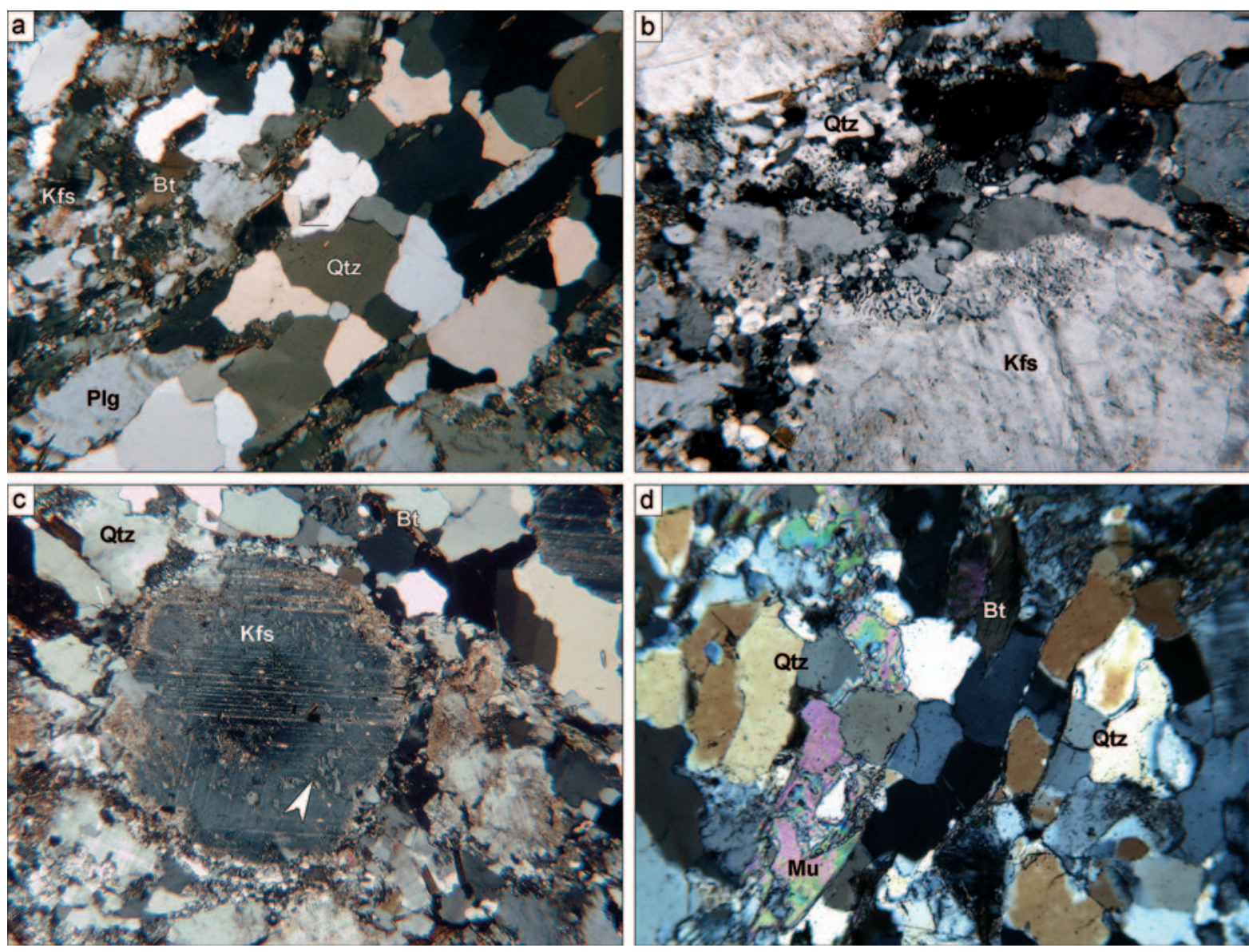

Fig. 6. Microstructures in the gneisses outside the main SJSZ (Östra Kuggskär, W and S Kökar). Key: Bt = biotite, Kfs = potassium feldspar, $\mathrm{Mu}=$ muscovite, $\mathrm{Plg}=$ plagioclase, $\mathrm{CPL}=$ cross-polarized light, $\mathrm{PPL}=$ plain-polarized light. a) $\mathrm{A}$ monomineralic quartz ribbon (lower left to upper right) in a granite gneiss, W Kökar. Most of the dynamic structures in quartz have been erased by recovery and high-T static recrystallisation, resulting in relatively strain-free grains (few subgrain boundaries or undulose extinction). The grains approach a polygonal appearance and the grain boundaries are relatively straight. However, the grain boundaries are slightly lobate in places and in one grain, a weak sub-grain rotation recrystallisation structure (white arrow) remains. Width of the view $4.5 \mathrm{~mm}$, CPL. b) Potassium feldspar - plagioclase myrmekites (centre) in a granite gneiss, W Kökar. The margins of the larger feldspar grains have been partly dynamically recrystallised by bulging (BLG), producing a rim consisting of very small feldspar crystals around the larger grain cores. Width of the view $1.8 \mathrm{~mm}$, CPL. c) A large, rounded plagioclase grain in a granite gneiss, W Kökar. The grain shows undulose extinction and remnants of an earlier (magmatic?) zoning (white arrow), as well as a narrow rim formed by BLG. Also the smaller feldspar grains around the large one have developed subtle BLG rims (lower left and right). The quartz ribbon (upper right) shows some lobate grain boundaries and undulose extinction, but the grains are relatively polygonal and strain-free. Width of the view $4.5 \mathrm{~mm}$, CPL. d) Mica schist, Östra Kuggskär. The quartz is mostly strain-free, with straight to weakly lobate grain boundaries. The rock is completely recrystallised, retaining a weak subvertical shapepreferred orientation of the quartz and feldspar grains. The schistose foliation is mainly defined by elongate mica grains and bands. Width of the view $1.8 \mathrm{~mm}, \mathrm{CPL}$. 

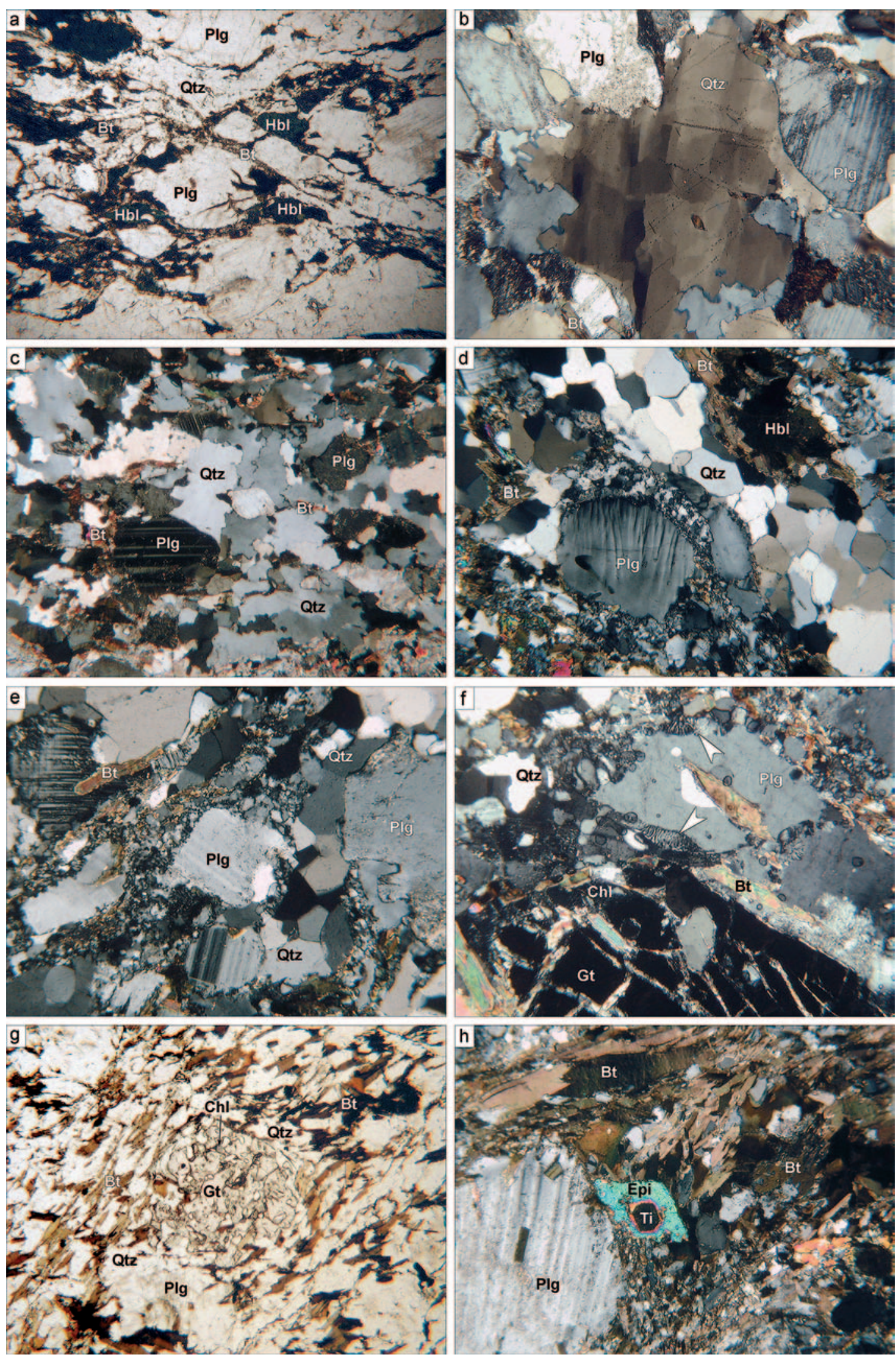
monly altered, brecciated and form lenses within the quartz-rich rocks, i.e. they show very little ductile deformation structures compared to the granitoids. Toward the main shear zone, somewhat lower-grade mineral assemblages become increasingly common in all rock types, especially in narrow, SJSZ-parallel high-strain zones ('shear bands'). The shear bands show a significant simple shear component and are some decimetres to 3-4 meters in thickness. They developed dominantly along the limbs of the open folds common on Hellsö, and/or at the contacts between two different rock types, although exceptions do occur (Torvela, 2007; Torvela \& Ehlers, 2010). Kinematic indicators with monoclinic symmetry in gneisses, largely absent in W and S Kökar, become more abundant within the high-strain zones of Hellsö. This is interpreted to reflect the overall pure shear that dominates on Kökar gradually giving way to localised simple sheardominated deformation toward the main shear zone (Torvela \& Ehlers, 2010). For example, weak C'type fabrics approaching a mylonitic appearance can be observed (Fig. 7a). These are kinematically consistent with the macrostructural interpretations presented in Torvela (2007) and Torvela \& Ehlers
(2010). The samples that seem to be transitional to mylonites could be defined as 'augengneisses' as small mica (mainly biotite) and recrystallised feldspar grains have concentrated in bands along the foliation between larger, often roundish feldspar grains and elongate quartz aggregates / ribbons (Fig. 7a). The rocks within the shear bands show dynamic microstructures such as highly lobate grain boundaries and 'chessboard extinction' of quartz grains (GBM and high-T SGR processes, Figs. 7b, c, respectively; Passchier \& Trouw, 2005; Stipp et al., 2002; Kruhl, 1996; Mainprice et al., 1986).

Between the shear bands, dynamic recrystallisation structures are less common while polygonal quartz grains, formed due to GBAR processes, are frequently observed between larger feldspar grains (Fig. 7d). These rocks, i.e. other than those within the shear bands, do however retain some dynamic recrystallisation structures. They typically show SGR and GBM recrystallisation, resulting in strain-free grains and slightly lobate grain boundaries in quartz. Contrary to the samples from the shear bands, highly lobate grain boundaries and chessboard extinction of quartz grains are not observed. In feldspar, some grains show remnants of myrmekitic and core-and-

Fig. 7. Microstructures in gneisses at the margin of the main SJSZ (Hellsö). Key: Bt = biotite, Chl = chlorite, Gt $=$ garnet, Epi = epidote, $\mathrm{Plg}=$ plagioclase, $\mathrm{Qtz}=$ quartz, $\mathrm{Ti}$ = titanite, $\mathrm{PPL}=$ plain-polarized light, $\mathrm{CPL}=$ cross-polarized light. a) Finegrained biotite around roundish feldspar grains (centre) in a granodioritic gneiss. This type of strongly sheared gneiss showing weak monoclinic shape symmetries, 'augen-gneisses', are probably precursors to the mylonitic deformation style. Width of the view $4.5 \mathrm{~mm}$, PPL. b, c) Dynamic medium- to high-T structures in a narrow (30-40 cm) shear zone in granodioritic gneiss, NW Hellsö. In b), the large quartz grain in the middle of the view displays 'chessboard extinction' (see text). Also the grain boundaries are clearly irregular and lobate due to grain boundary migration (GBM) processes. Width of the view $4.5 \mathrm{~mm}$, CPL. c) shows an almost monomineralic quartz band (centre left to centre right) where all quartz grains have been deformed by GBM, resulting in highly lobate grain boundaries. Width of the view $1.8 \mathrm{~mm}$, CPL. d) Static recovery of quartz in granite gneiss, Hellsö. GBAR resulted in strain-free, polygonal quartz grains in this quartz ribbon surrounding the central feldspar aggregate. The feldspar shows rim-and-mantle texture and deformation twinning. Width of the view $4.5 \mathrm{~mm}$, CPL. e, f) Dynamic structures in feldspars, granodioritic gneiss, Hellsö. In e), BLG recrystallisation of feldspars has resulted in core-and-mantle structures; the plagioclase grain in the centre of the view has developed weak 'wing' structures along the plane of the gneissose foliation (from lower left to upper right). Note also the strain-free, polygonal quartz grains. Width of the view $1.8 \mathrm{~mm}$, CPL. In f), some feldspar myrmekite can be seen in the centre of the view (white arrows). The quartz in this sample (upper left) has more irregular grain boundaries than in e) and shows some undulose extinction, but is still clearly more strain-free than the typical quartz grains within the narrow high-strain zones (see text and Figs. 7b, c). Width of the view $1.8 \mathrm{~mm}, \mathrm{CPL}$. g) Deflection of the gneissose foliation around a syntectonic garnet porphyroblast, granodioritic gneiss, Hellsö. The mica is red-brown biotite, unchloritised in this sample. Width of the view $4.5 \mathrm{~mm}$, PPL. h) Tonalitic gneiss, at a sheared contact between tonalite and granite, Hellsö. An epidote crystal pseudomorphing a titanite grain, the titanite remaining as a core within the epidote. The quartz in this sample is typically strain-free and polygonal (not visible), indicating post-deformation static recrystallisation (see text for discussion). Width of the view $1.8 \mathrm{~mm}$, CPL. 
mantle structures, much similarly to the gneisses outside the SJSZ on W and S Kökar (SGR and BLG; Figs. 7d-f). The feldspar occasionally shows weak undulose extinction. Garnet, only very locally present in the SJSZ rocks, is sometimes associated with biotite that might be a product of retrogressive alte- ration during deformation. In some samples, the garnet is slightly retrogressed to chlorite. The foliation is deflected around the garnets (Fig. 7e). The garnet porphyroblasts show inclusions that, however, do not define an internal foliation pattern $\left(S_{i}\right)$ within the porphyroblasts that deviates from the
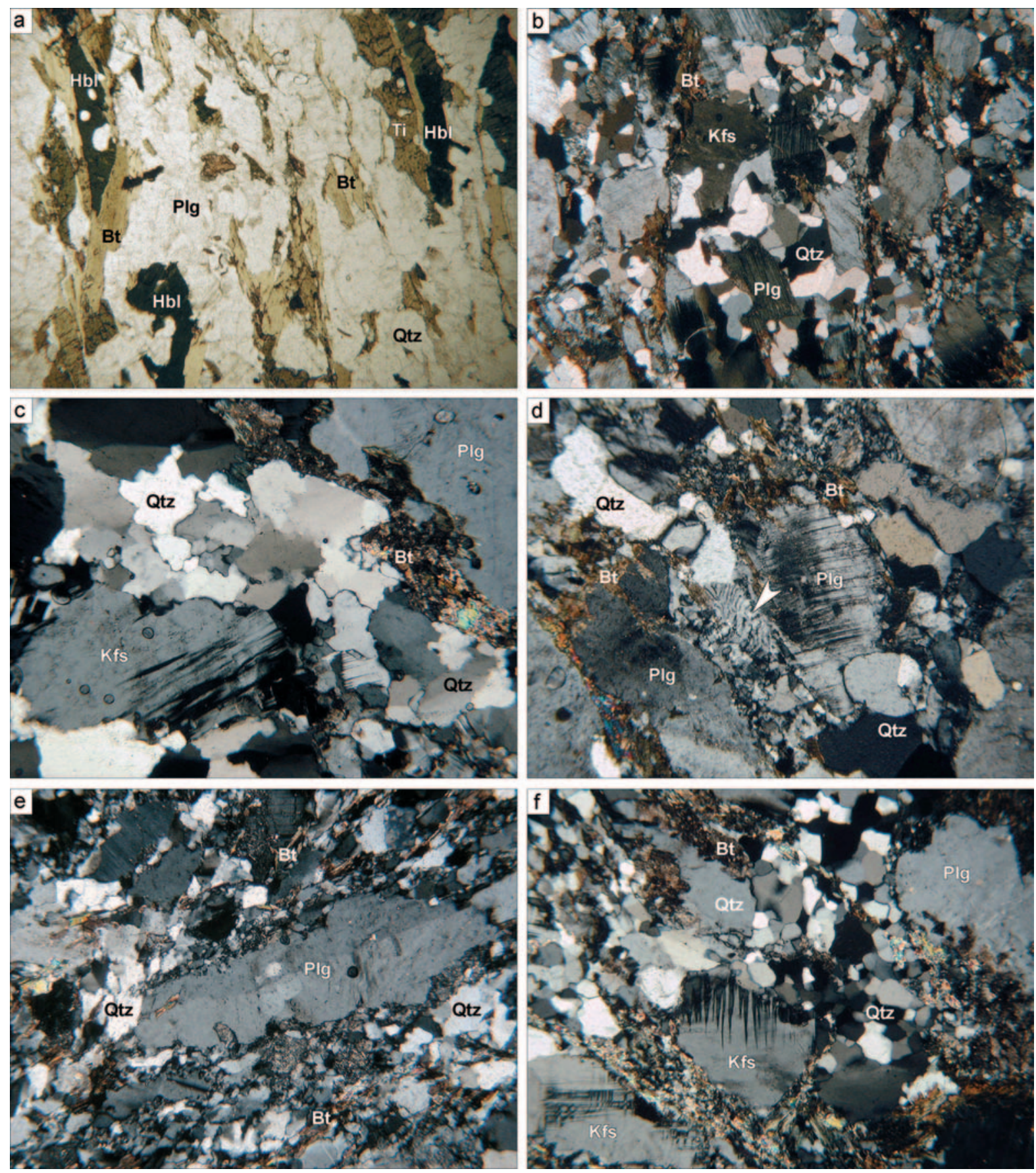
external foliation $\left(S_{e}\right)$ in the rest of the sample $\left(S_{i}=S_{e}\right)$.

Abundant titanite is present at the SJSZ margin. Titanite is almost always associated with amphibole, and epidote together with an opaque to almost opaque (very dark brown) phase is usually present (Fig. 7h).

The rocks within the SJSZ show increasing strain compared with the rocks at the shear zone margin. This is most obviously observed as a somewhat smaller overall grain size, better preserved dynamic microstructures and more distinct foliations due to the abundant quartz ribbons and bands, biotite-rich layers and slightly oblong crystals of feldspar, hornblende and titanite along the foliation (Fig. 8a). Gneisses approaching augen-like texture are relatively common within the shear zone. Static microstructures (GBAR) are markedly less common within the SJSZ than at the shear zone margins. However, some influence of syn- or postdeformational GBM recovery can be seen in most rocks as even the dynamically recrystallised grains often have a relatively strain-free appearance (Fig. 8b).

The dynamic recrystallisation structures observed within the SJSZ include lobate grain boundaries $(\mathrm{GBM})$ and SGR in quartz, while the feldspars frequently exhibit myrmekites and core-and-mantle structures (BLG; Figs. 8c, d). These dynamic recrystallisation structures are also observed in the $\sim$ 1.79 Ga microcline granite dykes on Sottunga (Fig. 8e) that show a foliation defined by quartz ribbons and oriented plagioclase grains. The gneisses surrounding the granite dykes show more abundant recovery fabrics, i.e. polygonal, strain free grains.

Deformation twins in plagioclase, flame-perthites (=tapering albite lamellae) in potassium feldspar and microfractures in feldspars are present locally within the shear zone (Figs. 8c, f). The rare garnet is mostly unaltered and has a 'ragged' appearance as it grew to enclose the surrounding, preexisting grains. Abundant titanite and, occasionally, epidote formed much similar to Hellsö, especially in the tonalitic rocks and metadiabases (Fig. 8a). Two titanite generations are present in many titanite-rich rock samples; one is clearly associated with the latest deformation fabric, while the presumably older one is darker brown and more turbid in thin section and unassociated with the foliation. Some of the SJSZ gneiss samples containing two titanite generations have been dated, giving absolute ages of $\sim 1.83 \mathrm{Ga}$ and $\sim 1.79 \mathrm{Ga}$ (unassociated and associated with the deformation fabric, respectively; Torvela et al., 2008).

\section{Mylonites}

Mylonites occur mainly as thick zones within the main SJSZ and within conjugate c. NE-SW striking shear zones (see Torvela \& Ehlers, 2010), although local, narrower mylonite zones have also

Fig. 8. Microstructures in gneisses within the SJSZ. Key: Bt = biotite, $\mathrm{Hbl}=$ hornblende, $\| \mathrm{I}=$ ilmenite/ilmenorutile, $\mathrm{Plg}=$ plagioclase, $\mathrm{Qtz}=$ quartz, $\mathrm{Ti}=$ titanite, $\mathrm{CPL}=$ cross-polarized light, $\mathrm{PPL}=$ plain-polarized light. a) A granodioritic-tonalitic gneiss, Kyrkogårdsö. The sample shows quartz bands and ribbons, and oblong hornblende and titanite grains, which together with biotite define the gneissose foliation. Width of the view $4.5 \mathrm{~mm}$, PPL. b) A granite gneiss, Storskär, Kyrkogårdsö. In some places within the shear zone, static recrystallisation and GBAR of quartz has removed most of the dynamic microstructures, leaving relatively strain-free, polygonised grains. This is, however, much less common than e.g. on Hellsö, at the shear zone margin. Width of the view 3.0 mm, CPL. c) A granite gneiss, Storskär, Kyrkogårdsö. The quartz grains in the ribbon at the centre (and lower left) of the view have irregular and lobate grain boundaries due to GBM recrystallisation. The grains are internally relatively strain-free, although some undulose extinction can be observed (lower right). Note also the potassium feldspar grain at lower left displaying flame-perthite. Width of the view $1.8 \mathrm{~mm}$, CPL. d) Feldspar myrmekite (white arrow) in a granite gneiss, Kyrkogårdsö. Note also the undulose extinction of the larger feldspar grains (centre and lower left). Width of the view $3.0 \mathrm{~mm}$, CPL. e) Elongated (magmatic) plagioclase grain surrounded by dynamically recrystallised quartz grains showing highly lobate grain boundaries. The orientation of the foliation defined by the quartz ribbons and the elongate grains is approximately E-W. A 1.79 Ga granite dyke, Sottunga. Width of the view $1.8 \mathrm{~mm}$, CPL. f) Flame perthite in a potassium feldspar grain (lower centre) in a granite gneiss, Storskär, Kyrkogårdsö. Note also the smaller quartz grains, presumably initially deformed by SGR but subsequently affected by static recovery, which resulted in a relatively straight grain boundaries and a weak foam structure. Width of the view $1.8 \mathrm{~mm}$, CPL. 
been observed. The thick mylonite zones (thickness from c. $1 \mathrm{~m}$ to tens of meters) follow the gneissose foliation and are consequently sometimes slightly folded, while the narrow mylonites (width $<1 \mathrm{~m}$, usually $1-10 \mathrm{~cm}$ ) sometimes cut the gneissose foliation. Examples of prominent wide mylonite zones have been encountered with e.g. on the island of Kyrkogårdsö and on the small islets east and southeast of Kökar main island (e.g. Norra Rödskär; Figs. 2, 4). Applying a distinction between protomylonites with 10-50\% matrix, mesomylonites with c. 50-90\% matrix and ultramylonites with $>90 \%$ matrix, the mylonites in the thick zones usually fall into the category of proto- to mesomylonites, but ultramylonitic varieties are occasionally present within the thickest mylonite zones. In the protomylonites and mesomylonites, the deformation is partitioned into relatively thin shear bands, observable in thin section as biotite-rich layers and quartz ribbons, leaving porphyroclasts, quartz ribbons, and/or lenses and bands retaining the gneissose fabric in between (Figs. 9a, b). Quartz in these mylonites is often strain-free and polygonal (Figs. 9a, b), although some retain dynamic structures (Fig. 9c). The tonalitic mylonites often have abundant titanite similarly to their gneissose counterparts (Figs. 9a, b). The rocks approaching an ultramylonitic appearance typically contain epidote, and commonly have more chlorite than the coarser mylonite varieties although chloritisation is very seldom extensive and brown biotite is the dominant matrix material. The high-grade mylonites are poor in kinematic indicators with monoclinic symmetry but, where observed, rotated porphyroclasts and weak C'-type fabrics indicate a dextral sense of shear (Figs 9d, 5c).

The narrow mylonite zones deflect and, more rarely, cut the gneissose foliation. They are commonly associated with the shear bands along the limbs of the mesoscale open folds on Hellsö (Torvela \& Ehlers, 2010). Microscope study of these mylonites reveals that the mylonitic texture is frequently a result of biotite-rich layers anastomosing between feldspar/amphibolite porphyroclasts and quartz lenses and ribbons. They are, therefore, relatively coarse-grained, very rarely approaching the ultramylonitic appearances observed within the thick mylonite zones. The narrow mylonites are typically not extensively chloritised.

\section{Cataclasites and pseudotachylytes}

Cataclasites and pseudotachylytes are rare but distinctive rock types found within and at the margins of the SJSZ. The cataclasites on Hellsö formed mainly along weakness zones in the gneisses (sometimes protomylonitic) that during later movements occasionally hosted pseudotachylytes. The cataclasites are usually amphibole- and biotite rich. The age of the cataclasites is unknown, but they are very probably younger than the mylonites but older than pseudotachylytes, based on field observations in the very few places where their mutual relationship can be seen. Some authors place the upper temperature limit for cataclastic deformation to c. $300{ }^{\circ} \mathrm{C}$ (e.g. Scholz, 1988). The cataclasites have not been studied extensively here, but the biotite in the brown Hellsö cataclasite matrix is not pervasively chloritised, which may imply that they were formed at relatively high- $\mathrm{T}$ conditions.

Pseudotachylytes have been found in two locations within the study area: on the islet of Storskär close to the island Kyrkogårdsö, and on Hellsö, northern Kökar, i.e. within and at the SJSZ margin, respectively. The pseudotachylytes in the two locations are here referred to in singular form ('the Storskär pseudotachylyte' and 'the Hellsö pseudotachylyte'), although each location contains multiple sets of paired first-order surfaces and associated conjugate fractures. However, since the pseudotachylyte sets in each location show similar and comparable features, they are here treated as single units. In both locations, the pseudotachylytes show steep (vertical) first-order surfaces striking NW-SE (c. $130^{\circ}$ ) on Storskär and approximately E-W on Hellsö.

The Storskär pseudotachylyte formed within the main shear zone, in a gneissose, sheared granodioritic wall rock showing steeply dipping, mostly regular and straight foliations striking c. $120-130^{\circ}$. 

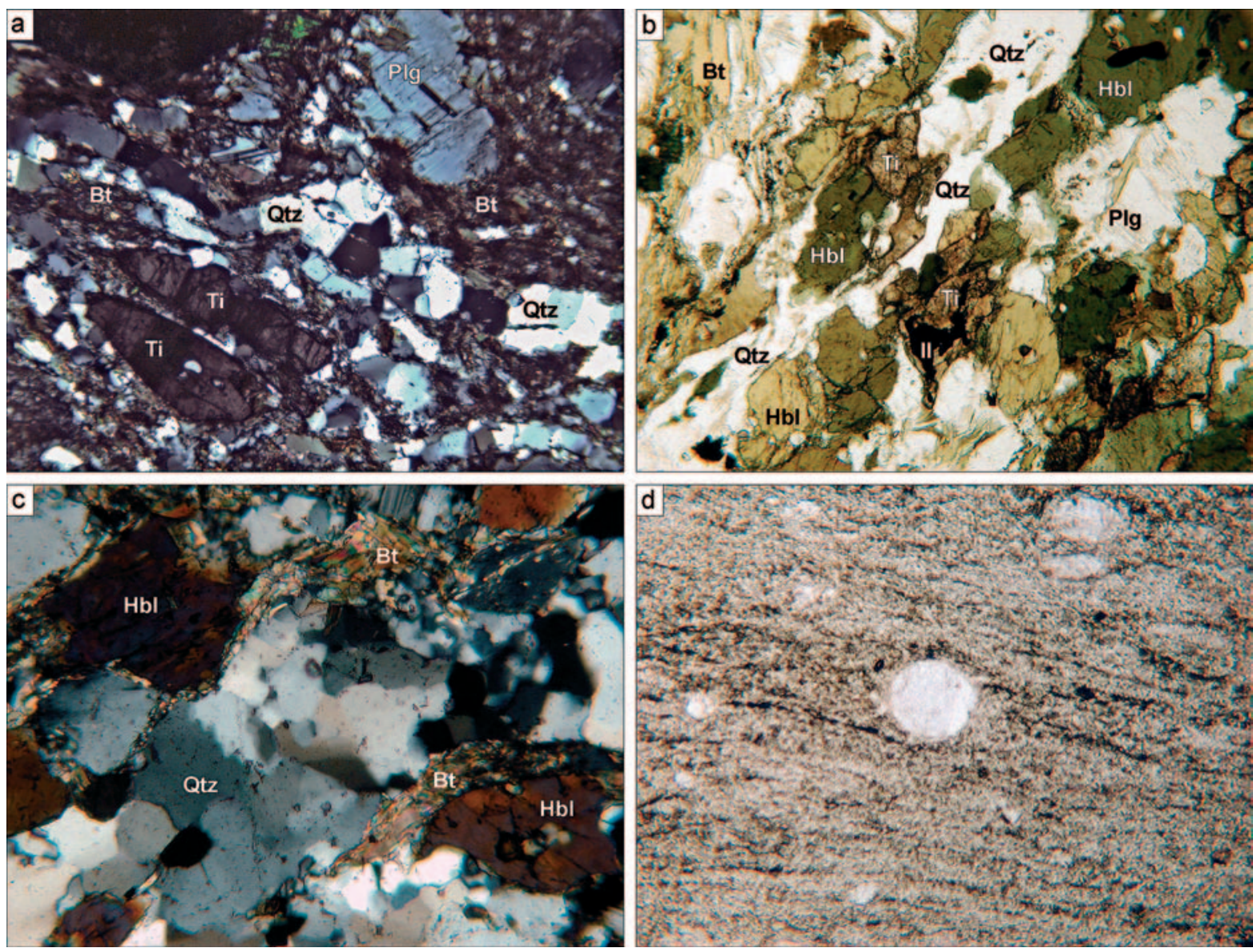

Fig. 9. Different mylonites within the study area. Key: $\mathrm{Bt}=$ biotite, Epi = epidote, $\mathrm{Hbl}=$ hornblende, II = ilmenite/ilmenorutile, $\mathrm{Mi}=$ microcline, $\mathrm{Plg}=$ plagioclase, $\mathrm{Qtz}=$ quartz, $\mathrm{Ti}=$ titanite, $\mathrm{CPL}=$ cross-polarized light, $\mathrm{PPL}=$ plain-polarized light. a) A mesomylonite, Norra Rödskär, SE of Kökar. The quartz ribbons in this rock show mainly polygonal, strain-free grains, evidencing of static recovery processes. The mylonitic foliation is defined by long bands of fine-grained, unchloritised biotite. The two titanite grains in the lower left corner have grown along the mylonitic foliation. Width of the view $1.8 \mathrm{~mm}$, CPL. b) A tonalitic protomylonite, Kyrkogårdsö. The mylonitic appearance is defined mainly by the monomineralic quartz ribbons (lower left to upper right) and narrow layers of very fine-grained biotite. The titanite grown into the mylonitic fabric in this sample has been dated at $\sim 1.79 \mathrm{Ga}$ (Torvela et al. 2008). Width of the view $4.5 \mathrm{~mm}$, PPL. c) Subgrain rotation recrystallisation (SGR) and somewhat lobate grain boundaries formed in response to GBM recrystallisation in a quartz ribbon within a tonalitic protomylonite, Kyrkogårsö. Despite the intense deformation, the quartz has a strain-free appearance due to recovery processes during the deformation. Width of the view $74 \mu \mathrm{m}, \mathrm{CPL}$. d) A rounded plagioclase $\sigma$-clast with poorly developed wings in a granodioritic ultramylonite, Kyrkogårdsö. The matrix consists mainly of quartz/feldspar, biotite and opaque minerals, with minor chlorite and epidote. Width of the view $4.5 \mathrm{~mm}$, PPL.

The pseudotachylyte formed without cataclastic or mylonitic precursors, the first-order surfaces being relatively straight and close to parallel with the gneissose foliation in most parts. In contrast, the Hellsö pseudotachylyte surfaces are more anastomosing and associated with older, mylonitic and/or cataclastic zones. It appears from the field evidence that the mylonites and cataclasites had some local control on the orientation of the pseudotachylyte first-order surfaces (Torvela \& Ehlers, 2010).

The Kyrkogårdsö and Hellsö pseudotachylytes are mainly composed of a very fine-grained (aphanitic), almost isotropic matrix with tiny porphyroclasts of quartz and/or feldspars (Figs. 10a, c), but also newly crystallised, needle-like feldspar crystals (microlites) are common so that the pseudotachy- 

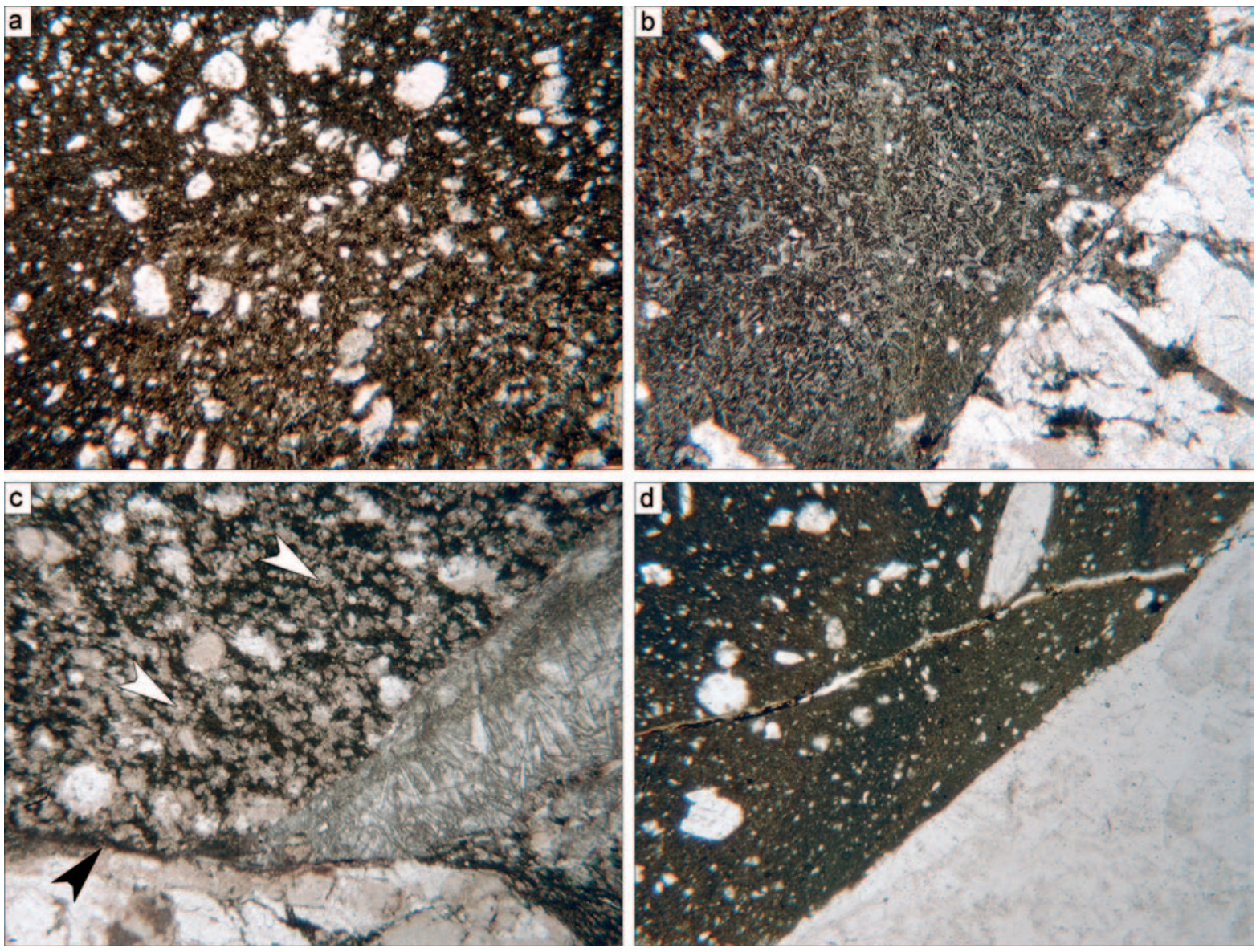

Fig. 10. Pseudotachylytes within the study area. Key: $\mathrm{CPL}=$ cross-polarized light , PPL = plain-polarized light. a) A zoned pseudotachylyte injection vein on Storskär, Kyrkogårdsö. The melt further away from the vein walls probably crystallised slightly slower, resulting in a somewhat less glassy matrix with a lighter colour (centre to lower right). The clast/matrix ratio in this sample is 0.35 . Width of the view $4.5 \mathrm{~mm}$, PPL. b) A pseudotachylyte injection vein from Storskär, Kyrkogårdsö. The pseudotachylyte has a slightly more fine-grained 'chilled margin' against the granodioritic wall rock. Note also the abundant small, needle-shaped plagioclase microlites within the pseudotachylyte melt close to the contact with the gneiss, and how the microlites gradually become less abundant toward the centre of the vein (upper left). Width of the view $4.5 \mathrm{~mm}$, PPL. c) A pseudotachylyte formed along a main fault vein (generation surface), Hellsö (sample K-8/02). The pseudotachylyte melt shows a weak flow texture (from upper left toward centre), probably formed as the melt moved along the surface. The sample is rich with small, reddish feldspar spherulites (white arrows), making the determination of the clast/melt ratio very difficult. A later (?) crack cutting the pseudotachylyte is filled with crystals of the epidote group. The epidote crack is here in turn offset by a later, brittle microfracture (black arrow). Width of the view $4.5 \mathrm{~mm}$, PPL. d) A pseudotachylyte within a granitic gneiss, Torsholma (not within the study area; see chapter Interpretations). The matrix is glassy and largely unvitrified, and the clast/melt ratio is calculated to 0.2 . Width of the view $4.5 \mathrm{~mm}$.

lytes occasionally approach an ophitic appearance (Fig. 10b). Some larger (up to $3 \mathrm{~cm}$ ) melt pockets show zoning visible with the naked eye, although in thin section, the crystallisation zones do not appear to differ mineralogically; only a slight colour change can be observed (Figs. 10a). The larger melt pockets also show a very narrow chilled margin against the gneissose host rock (Figs. 10b). Some of the Hellsö pseudotachylytes show weak flow structures that probably formed when the melts moved along the fault surfaces. In Hellsö pseudotachylyte, cracks filled with crystals of the epidote group formed locally along the pseudotachylyte fault surfaces (Fig. 10c). 


\section{Interpretation}

Microstructural differences between the quartz-rich and quartz-poor rock types $S W$ of the $S J S Z$ (Fig. 6) are relatively small as both have commonly undergone extensive post-deformation static recrystallisation at relatively high-T conditions. Nevertheless, the granitoids show many features indicating dynamic recrystallisation that are absent in the mafic rocks because the lack of quartz and potassium feldspar made the mafic rocks rheologically stronger; amphibole, for example, deforms mainly by brittle fracturing and dissolution-precipitation rather than crystal-plastic deformation and recrystallisation at temperatures below c. $650-700^{\circ} \mathrm{C}$ (e.g. Imon et al., 2002; Berger \& Stünitz, 1996). The thin sections from the felsic gneisses of $\mathrm{W}$ and $S$ Kökar show relatively high-T $\left(500-700{ }^{\circ} \mathrm{C}\right)$ dynamic recrystallisation microstructures; the differences in the rheological behaviour between quartz and feldspars at the prevailing conditions are visible. In feldspars, relatively high- $\mathrm{T}\left(500-600^{\circ} \mathrm{C}\right)$ indicators such as myrmekites and core and mantle structures can be observed. Subgrain structures in feldspar (deformation above c. $600^{\circ} \mathrm{C}$; Vidal et al., 1980; Olsen \& Kohlstedt, 1985; Pryer, 1993; Altenberger \& Wilhelm, 2000) are not observed, although intragrain structures may have been completely removed by (static) recrystallisation and recovery processes. The monomineralic quartz ribbons and patches with relatively strain-free grains and polygonised grain boundaries formed as a result of grain boundary area reduction processes (GBAR; e.g. Passchier \& Trouw, 2005; Evans et al., 2001). Most of the observable recrystallisation and recovery structures are, therefore, probably static i.e. formed after the deformation waned, implying that the temperatures remained elevated for some time after peak deformation in the SW.

At the shear zone margin (Fig. 7), highly lobate grain boundaries and 'chessboard extinction' of quartz grains within the shear bands are indicative of dynamic microstructures associated with temperatures around $500-700{ }^{\circ} \mathrm{C}$ (Passchier \& Trouw, 2005; Stipp et al., 2002; Kruhl, 1996; Mainprice et al., 1986). In the rocks outside the shear bands, dynamic recrystallisation structures are less common but the recorded evidence of SGR and GBM recrystallisation processes indicate temperatures in the range of 500-700 ${ }^{\circ} \mathrm{C}$ (Jessell, 1987; Stipp et al., 2002). The remnant myrmekitic and core-andmantle structures in feldspar further pinpoint the metamorphic temperature during the deformation to c. $500-600{ }^{\circ} \mathrm{C}$ (Gapais, 1989; Tullis \& Yund, 1991). The rare garnet is sometimes slightly retrogressively chloritised. The foliation is deflected around the garnets, indicating that the garnet developed during or before active deformation.

Compared to the shear zone margin, the increasing abundance of mylonitic deformation and dynamic microstructures in the gneisses within the SJSZ (Fig. 8) is probably due to the higher deformation intensity and/or prolonged deformation along the shear zone. The dynamic recrystallisation structures observed in the SJSZ gneisses indicate temperature conditions around $500-700{ }^{\circ} \mathrm{C}$; the quartz commonly shows lobate grain boundaries (GBM) and SGR, while the feldspars frequently exhibit myrmekites and core-and-mantle structures. The locally present deformation twins in plagioclase, flame-perthites in potassium feldspar, and undulose extinction and microfractures in feldspars commonly form at deformation temperatures between c. $400-500^{\circ} \mathrm{C}$, although these structures can also form at temperatures up to c. $600^{\circ} \mathrm{C}$ (e.g. Tullis \& Yund, 1987; Pryer, 1993; Pryer \& Robin, 1995). The last stage of extensive ductile deformation (shearing) within the SJSZ therefore occurred in temperatures of c. $500-700^{\circ} \mathrm{C}$, probably closer to $500{ }^{\circ} \mathrm{C}$ than to $700{ }^{\circ} \mathrm{C}$.

In the SJSZ protomylonites (Fig. 9), the microstructures preserved in the lenses surrounded by biotite-rich shear bands imply deformation at 500-700 ${ }^{\circ} \mathrm{C}$, at least during the last ductile deformation phase in a high-grade environment, as SGR and lobate quartz grain boundaries (GBM) in monomineralic quartz ribbons are common. The proto- and mesomylonitic rocks do not generally show extensive chloritisation of the mafic minerals, which further pinpoints the temperature conditions of this deformation phase to around $550^{\circ} \mathrm{C}$ (Laird, 1980; Moody et al., 1982). 
The conditions of the ultramylonitic deformation (Fig. 9) within the wide zones are more difficult to constrain. The matrix of the ultramylonites is very fine grained, probably resulting from extreme GBM recrystallisation processes as biotite behaves ductilely at temperatures above c. $250{ }^{\circ} \mathrm{C}$ (Bell, 1998). Chloritisation exists locally but is very seldom extensive. Instead, brown biotite is the dominant matrix material, implying that the matrix formed at a temperature high enough to prevent significant chloritisation, although the ultramylonites typically contain abundant epidote, a mineral commonly indicative of greenschist facies conditions. However, according to experiments by Moody et al. (1982) and Liou et al. (1974), epidote can be stable at temperatures as high as $600^{\circ} \mathrm{C}$ at high $\mathrm{f}_{\mathrm{O} 2}$, especially in basic rocks. Abundant titanite in the rocks implies high $\mathrm{f}_{\mathrm{O} 2}$ which will be discussed below. Consequently, we interpret that the ultramylonitic deformation took place in relatively highgrade conditions, probably within the amphibolite-greenschist facies transition (c. $500^{\circ} \mathrm{C}$ ). No evidence of brittle deformation processes has been found. In all mylonite types, the sense of shear is exclusively dextral, indicating a continued convergence from the south.

\section{Discussion}

According to Torvela et al. (2008) and Torvela \& Ehlers (2010), the regional deformation in the area can be divided into three ductile phases (D2, D3 and D4 at $\sim 1.85 \mathrm{Ga},-1.83-1.82 \mathrm{Ga}$ and $\sim 1.79$ $\mathrm{Ga}$, respectively) and at least one (semi)brittle phase; by D3, the shear zone was already well developed. To avoid confusion, D1 is not considered here because D1 in the Fennoscandian context usually refers to an early (Fennian; Lahtinen et al., 2005) deformation phase not recognised in the area of this study. D3 corresponds best to the $-1.84-1.80 \mathrm{Ga}$ Svecobaltic orogeny of Lahtinen et al. (2005) and is approximately simultaneous with the late phase of LSGM anatectic granite magmatism and migmatisation at $\sim 1.85-1.82$ (e.g. Kurhila et al. 2005). However, magmatism and extensive migmatisation of that age have not been observed within and to the south of the SJSZ.

By D4, the deformation was largely partitioned into the main SJSZ and the relatively narrow high-strain zones along the SJSZ margin (Torvela et al., 2008; Torvela \& Ehlers, 2010). The dynamic microstructures within the SJSZ and its margins are therefore allocated mainly to the D4 deformation phase. However, the microstructures observed within the narrow shear bands on Hellsö (the chessboard structure) witness of somewhat higher deformation temperatures than those within the SJSZ and, therefore, possibly represent an earlier deformation phase (D3, or early D4). D4 within the SJSZ was a ductile, lower amphibolite facies, approximately N-S directed compressive event until at least $\sim 1.79 \mathrm{Ga}$ as witnessed by the strong correlation of the deformation fabrics and the titanite in the dated (unchloritised) SJSZ protomylonite and metadiabase (U-Pb ages; Torvela et al., 2008). This is further confirmed by the $\sim 1.79 \mathrm{Ga} \mathrm{U}-\mathrm{Pb}$ zircon magmatic age of the ductilely deformed pre-Mosshaga microcline granite dykes on Sottunga in the NW part of the shear zone (Fig. 8e; Ehlers et al., 2004). The dykes are folded and, assuming that they were originally relatively planar, show up to $50 \%$ shortening in a N-S to NNE-SSW direction (Fig. 11). The orientation of the deformation fabrics in the -1.79 Ga microcline granite dykes does not correlate with the boundaries of the 1788 Ma Mosshaga pluton $-\mathrm{NW}$ of Sottunga (U-Pb zircon age; Welin et al., 1983), implying that the fabrics did not result from the intrusion of the pluton into the crust. The Mosshaga pluton itself is largely undeformed, indicating cessation of the ductile deformation soon after its intrusion, although it does host an E-W synmagmatic orientation of microcline megacrysts (Welin et al., 1983). The last ductile compressive phase D4 at $\sim 1.79 \mathrm{Ga}$ implies that the rocks had not yet reached the brittle-ductile transition at that time. The age is coeval with the late stages of the Nordic orogeny of Lahtinen et al. (2005, and references therein). However, the convergence and subduction of the Nordic orogeny was from NW-WNW, while the attitude of the late (D4; $-1.79 \mathrm{Ga}$ ) ductile fabrics and structures in the SJSZ 


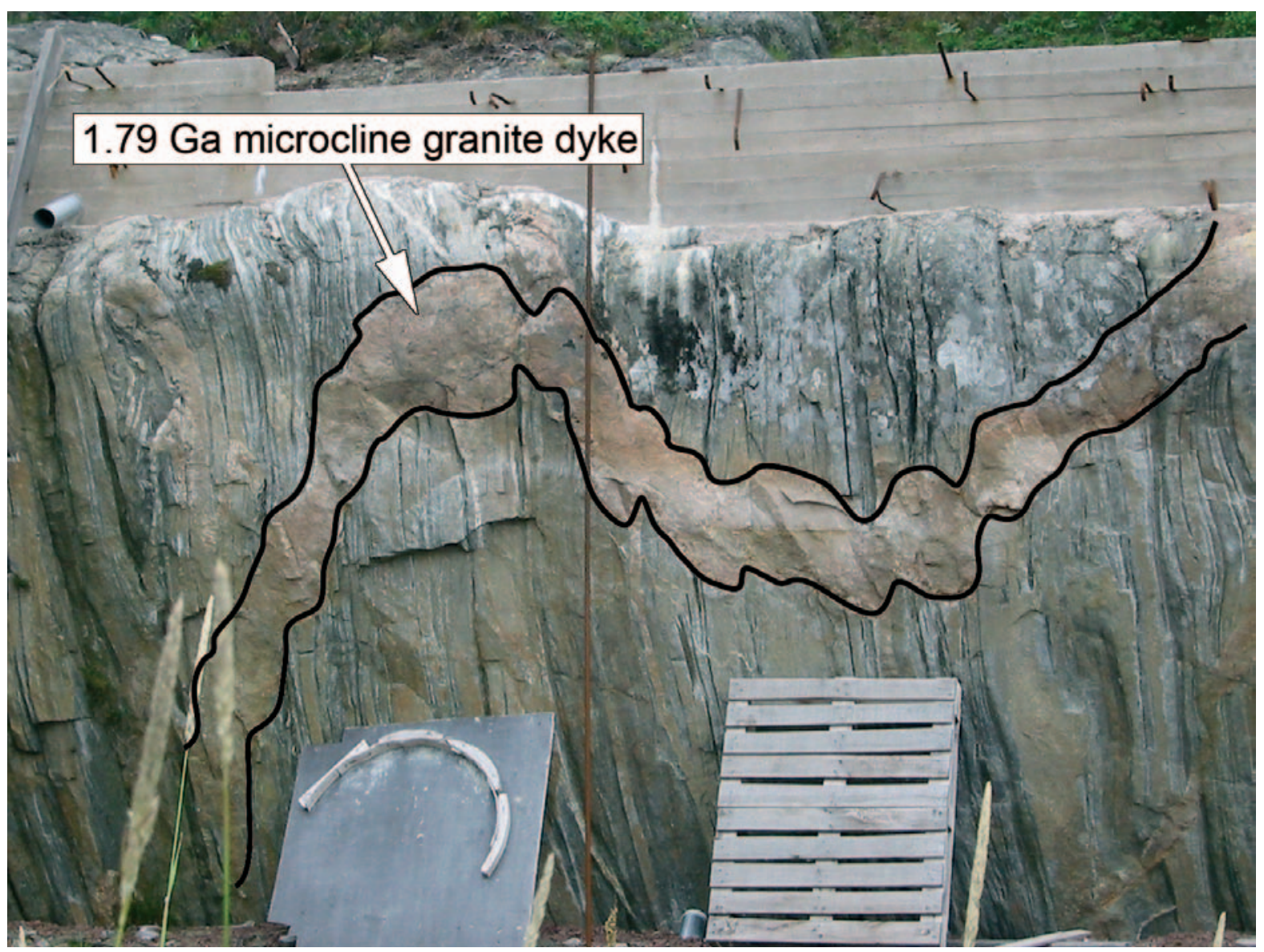

Fig. 11. A folded, $\sim 1.79 \mathrm{Ga}$ granite dyke on Sottunga, showing an approximate shortening factor of $e=\left(I-I_{0}\right) / I_{0}=-0.4$, i.e. approximately $40 \%$ of shortening. This, in turn, implies that compression/transpression was still active during or after the intrusion of the dyke. View toward NW, height of the cliff face c. $2 \mathrm{~m}$.

area indicate approximately N-S -directed transpression (Torvela et al., 2008; Torvela \& Ehlers, 2010; this paper). This suggests that the convergence from WNW did not significantly affect the crust in SW Åland area at $\sim 1.79 \mathrm{Ga}$. Similar results have been obtained from south-central Sweden where N-S shortening produced ductile shear zones until at least $\sim 1.80 \mathrm{Ga}$ (e.g. Högdahl et al., 2009). We follow our previous results (Torvela \& Ehlers, 2010) in concluding that the SJSZ forms a part of a terrane boundary (a 'Trans-Fennoscandian deformation zone') that compartmentalised the far-field orogenic stresses; in central Fennoscandia, the area to the north of the zone was affected by the Nordic orogeny and by the collision of Sarmatia from the SE, while the rocks to the south of the SJSZ responded to a convergence from the S-SSW (Fig. 3). The late ductile microstructures are, therefore, here allocated to the convergence of an unknown crustal block or a microcontinent from S-SSW at $-1.79 \mathrm{Ga}$, an event also suggested by Lahtinen et al. (2005).

In the rocks outside the SJSZ, deformationrelated dynamic microstructures are mostly absent as static recrystallisation processes have destroyed most of the earlier dynamic recrystallisation structures in the rocks. However, it is feasible that the continuing convergence during (D3-)D4 still affected the rocks outside the main shear zone in order to accommodate the flattening component of the regional transpressive stresses. Therefore, the dynamic microstructures that remain in these rocks probably formed during (D3-)D4, despite the fact 
that deformation at this stage was not very intense in $S$ and W Kökar so that at a larger scale, earlier (D2-D3) structures were preserved (Torvela \& Ehlers, 2010). Lower-T dynamic microstructures of the last ductile deformation phase such as feldspar microfracturing or deformation twins have not been observed on W and S Kökar or in Hellsö gneisses, confirming that the D4 was dominantly localised to the main shear zone.

Especially in the tonalitic samples, one or two titanite generations are often present, exclusively associated with amphibole and magnetite/ilmenite, with or without epidote. According to Xirouchakis et al. (2001), titanite (and magnetite) associated with amphibole is common in plutonic quartz-rich rocks and is indicative of a high water activity $\left(\mathrm{a}_{\mathrm{H} 2 \mathrm{O}}\right)$ and high oxygen fugacity $\left(\mathrm{f}_{\mathrm{O} 2}\right)$ in igneous and metamorphic rocks. They further conclude that the titanite-forming process is most efficient at slow cooling rates at temperatures relatively high compared to solidus-temperatures of the magmas (up to upper amphibolite facies). The microstructures presented in this paper are compatible with a slow cooling rate, at least from D3 to D4 (cf. the somewhat higher-grade microstructures in shear zones at SJSZ margin, as opposed to the lower-grade structures within the SJSZ). Also the presence of epidote (without other minerals indicative of greenschist facies conditions) in many samples suggests a high $\mathrm{f}_{\mathrm{O} 2}$ (Moody et al., 1982). The epidote may be a dissolution product of amphibole, as amphibole mostly deforms by brittle deformation and dissolution-precipitation processes resulting in a deposition of e.g. albite, biotite and epidote at temperatures below c. 650-700 ${ }^{\circ} \mathrm{C}$ (e.g. Berger \& Stünitz, 1996). The presence of epidote may also be allocated to titanite alteration processes, where titanite is replaced by ilmenite, quartz, epidote (REE-bearing) and allanite according to the reaction titanite + anorthite + annite $+\mathrm{H} 2 \mathrm{O}=$ ilmenite + clinozoisite + muscovite + quartz, in the system KCFATSHO (Broska et al., 2007). In some samples. the epidote is associated with a (presumably) older titanite generation, implying that it formed mainly as a result of titanite alteration processes, while in other samples, there is no clear association with titanite (old or young) and the epidote, suggesting that also the amphibolite dissolution may have played a role in the epidote formation.

The lower-grade, retrograde mineral reactions locally present in the gneisses at the shear zone margin on Hellsö and within the SJSZ often occur within zones of relatively high strain. However, in most samples the reactions seem to be completely absent, also in samples exhibiting high strains. Fluid channelling, i.e. variations in the amount of fluids present in different parts of the rock, may have affected the distribution of retrogressive reactions. Our interpretation is that, since the retrogressive reactions are not present everywhere, the reactions occurred mainly during the late stage of or after D4; the ductile D4 deformation resulted in high-strain zones, some of which later acted as channels for fluids that enabled retrogressive reactions as the rocks cooled. During this late- to post- D4 period, the rocks passed through retrograde, lower amphibolite facies conditions where hornblende and the occasional garnet start to alter to biotite and, locally, further to chlorite. The chloritisation reaction initiates at $\mathrm{c}$. $550{ }^{\circ} \mathrm{C}$ in siliceous alkali-calcic rocks, alkalic rocks and basic rocks, although in basic rocks chlorite can appear at higher temperatures at high $\mathrm{f}_{\mathrm{O} 2}$ (e.g. Evans, 1990; Moody et al., 1982). Retrograde alteration is indeed more common in the intermediate and mafic rocks, so rock geochemistry has also played a role in the distribution of the retrograde reactions. The temperature drop after D4, probably due to the exhumation of the rocks, must in any case have been quite fast from amphibolite-greenschist facies transition toward cooler conditions since even when retrograde reactions do occur (due to fluid channelling or geochemistry) they are not very extensive. On the other hand, the static recrystallisation structures in samples affected by the D4 deformation within the SJSZ suggests that before the temperature drop, the temperature remained elevated for a short period of time after the pervasive, active D4 deformation ceased.

Also in the mylonites, the lack of extensive retrogression suggests that they were formed at relatively high temperatures (lower amphibolite facies). Since the mylonites represent the last defor- 
mation phase commonly recorded in the rocks before the cataclastic-pseudotachylitic phase $(s)$, the temperature probably dropped fast after the rocks reached amphibolite-greenschist facies transition, and/or there was a break in regional deformation while the rocks cooled and/or exhumed. The abundance of hydrous minerals and minerals requiring high $\mathrm{f}_{\mathrm{O} 2}$ (biotite, titanite, hornblende, epidote) suggest that fluids were present during mylonitisation, so the scarcity of chlorite should not be caused by lack of fluids to facilitate the retrograde reactions. As the chloritisation reaction occurs from c. 550 ${ }^{\circ} \mathrm{C}$ and below in siliceous alkali-calcic rocks and alkalic rocks, the higher temperatures being favoured by a high $\mathrm{f}_{\mathrm{O} 2}$ (e.g. Evans, 1990; Moody et al., 1982), it is reasonable to conclude that the at least the studied mylonites must have been formed at relatively high-T conditions (around $500{ }^{\circ} \mathrm{C}$ ), and that the temperature dropped rapidly soon after the mylonitisation. We, therefore, suggest that these mylonites formed mainly during D4 as a result of extreme deformation partitioning and high strain rates and to a lesser extent by repeated reactivation of earlier high-strain zones after D4. In other words, the locally higher strain rates and thereof resulting enhancement of strain softening processes caused relatively high-T mylonitisation more or less simultaneously with the last gneissose deformation phase D4 (White et al., 1980; Passchier \& Trouw, 2005). In addition, there are some indications that an earlier (D3) mylonitisation phase may have taken place at $1.83-1.82 \mathrm{Ga}$ (Torvela et al., 2008).

As for the pseudotachylytes (Fig. 10), some of the microscopic features suggest that they were not formed very close to the surface. Firstly, the matrix in the observed pseudotachylytes is not glassy but very fine-grained and commonly contains abundant, small spherulites, in places even plagioclase microlites so that the resulting texture approaches an ophitic appearance. However, the aphanitic rather than glassy grain size and the spherulites may also result from devitrification processes instead of melt crystallisation processes (devitrification being a process where pseudotachylyte glass alters to stable crystalline material in near-surface conditions; e.g. Lin, 1994). On the other hand, the sub-ophitic texture defined by the acicular plagioclase microlites seen in some pseudotachylyte samples (Fig. 10b) could not have formed as a result of devitrification, suggesting that at least a part of the melt crystallised rather than froze into glass. The lowest temperature estimate for the formation of crystalline (microlitic) pseudotachylyte is $150-200{ }^{\circ} \mathrm{C}$ (e.g. Scholz, 1988). Secondly, the larger melt pockets, as described above, show some crystallisation zoning, probably indicating a sequence of crystallisation where the outer parts of the melt pockets crystallised/froze more rapidly than the inner parts. Thirdly, the clast/melt ratio (W/M) is quite low; when the microscope photos of Kökar and Kyrkogårdsö pseudotachylytes are analysed with image analysis software (Digimizer 3.0 by Frank Schoonjans, 12 photos analysed), the obtained W/M lies between 0.2-0.35. According to O'Hara (2001), W/M of pseudotachylytes in general is between $0.1-0.7$. A low ratio indicates a high temperature for the pseudotachylytehosting country rock at the time of pseudotachylyte formation, and vice versa; a relatively high country rock temperature results in fewer clasts in the pseudotachylyte than a lower country rock temperature. O'Hara (2001) also presents a pseudotachylyte geothermometer, where $\mathrm{T}(\mathrm{K})_{\text {crust }}=(1-\mathrm{W} / \mathrm{M}) \mathrm{T}(\mathrm{K})_{\text {melt }}$ (the accuracy of the method is $\pm 70{ }^{\circ} \mathrm{C}$ ). Using this formula, temperatures of c. $400^{\circ} \mathrm{C}$ and $5300^{\circ} \mathrm{C}$ can be calculated for country rocks hosting pseudotachylytes with clast/melt ratios of 0.35 and 0.2 , respectively, if a pseudotachylyte melt temperature of 750 ${ }^{\circ} \mathrm{C}$ is assumed. This temperature is a minimum since pseudotachylyte melts are usually considered to have temperatures between $750-1600{ }^{\circ} \mathrm{C}$ (e.g. DiToro \& Pennacchioni, 2004; O'Hara, 2001; Lin \& Shimamoto, 1998). A calculation applying higher melt temperatures would give even higher country rock temperatures, completely unrealistic for the study area. The country rocks are quartzo-feldspatic and rich in hydrous minerals, so relatively low melt temperatures could be expected, even in a case of non-equilibrium melting associated with pseudotachylyte formation. Nevertheless, the country rock temperature calculated for W/M of 0.2 (530 $\left.{ }^{\circ} \mathrm{C}\right)$ seems high, although not impossible considering the structural context and the petrographic 
evidence, while the temperature calculated for ratio $0.35\left(400^{\circ} \mathrm{C}\right)$ seems more realistic. The possible devitrification processes (spherulites) observed in thin section may have obscured the true abundance of especially the smaller clasts in some samples, in which case the image analysis would give too low clast/melt ratios, i.e. to high temperatures, for the studied (devitrified) samples. On the other hand, when an undevitrified pseudotachylyte sample from Torsholma, c. $40 \mathrm{~km}$ north of Kökar (outside the area of this study), was analysed for comparison, a clast $/$ melt ratio of $0.2\left(530^{\circ} \mathrm{C}\right)$ was obtained (Fig. 10d). Despite their uncertainties, the temperature calculations together with the microstructural observations give a clear indication that the pseudotachylytes were formed at relatively high crustal temperatures, probably well within the ductile-brittle transition zone. The depth of this transition varies greatly depending on many factors such as geothermal gradient, lithotype, strain rate, fluid pressure, grain size and pre-existing fabrics. The transition zone is by many authors placed between c. 300$500{ }^{\circ} \mathrm{C}$, i.e. $10-15 \mathrm{~km}$, for pelitic and quartzofeldspatic rocks, the upper ('cold') limit roughly corresponding to the cessation of feldspar plasticity (e.g. Pennacchioni \& Cesare, 1997; McNulty, 1995; Tullis \& Yund, 1987). No overprinting of the pseudotachylytes by more ductile phases (mylonites) have been observed in the SJSZ area, which would be a definite, but not required, indication of a relatively high country rock temperature during the pseudotachylyte-forming event.

The microstructural observations presented in this paper support the conclusions by Torvela $\&$ Annersten (2005) that the peak deformation within and at the margin of the SJSZ occurred at c. $635-670{ }^{\circ} \mathrm{C}$, while the retrogressive ductile deformation path is recorded at c. $500-610{ }^{\circ} \mathrm{C}$ (Gt-Bt geothermometer; the corresponding pressures, calculated with the GPBQ geobarometer, are 6.3-6.7 kbar and 5.3-5.6 kbar, respectively). The higher 'peak' temperatures are, on the basis of the observations presented in this paper, allocated to the D3 deformation phase, while the retrogressive temperature estimates represent the approximate temperature for the D4 deformation. The temperature of c. $500{ }^{\circ} \mathrm{C}$ probably reflects the late $\mathrm{D} 4$ conditions. Assuming a geothermal gradient of $35^{\circ} \mathrm{C} / \mathrm{km}$, the exhumation rate from 1.83 to $1.79 \mathrm{Ga}$ would be approximately $0.000105 \mathrm{~m} / \mathrm{a}$. The pressure calculations of Torvela \& Annersten (2005) indicate a similar magnitude, $0.000079 \mathrm{~m} / \mathrm{a}$, for the exhumation rate from $6.5 \mathrm{kbar}(-1.83 \mathrm{Ga})$ to $5.45 \mathrm{kbar}$ $(-1.79 \mathrm{Ga})$ within the area of this study. On the other hand, Welin et al. (1983) suggest that the 1788 Ma Mosshaga pluton intruded at a depth of 7-10 $\mathrm{km}$, i.e. around $2-3 \mathrm{kbar}$. Therefore, the exhumation rate between late D4 and the intrusion of the Mosshaga pluton seems to have been very rapid, around $0.003 \mathrm{~m} / \mathrm{a}$ (from c. $5.3 \mathrm{kbar}$ to $2-3 \mathrm{kbar}$ in 2-3 Ma). In the Turku area (within the LSGM), peak metamorphism occurred at c. $800{ }^{\circ} \mathrm{C}$ and 5 kbar from $1.83 \mathrm{Ga}$ onwards, and the rocks were at c. 4 kbar at $-1815 \mathrm{Ma}$ (Väisänen et al., 2000), giving an exhumation rate of c. 0.00015 and 00013 $\mathrm{m} / \mathrm{a}$ for $1830-1815 \mathrm{Ma}$ and $1815-1788 \mathrm{Ma}$, respectively.

\section{Summary}

Based on the microstructural evidence, at least the last two ductile deformation phases (D3 and D4) took place within amphibolite facies and amphibolite-greenschist facies transitional conditions, respectively. The deformation phases are allocated to the metamorphic ages obtained in earlier studies, i.e. $-1.83-1.82 \mathrm{Ga}$ (D3) and $1.79 \mathrm{Ga}$ (D4). Substantial recovery and static recrystallisation took place during and after both deformation phases, quite effectively erasing the dynamic structures in all but the most intensely deformed rocks. However, some dynamic structures remain and indicate that during $\mathrm{D} 3$ and $\mathrm{D} 4$, the temperatures were between $500-700{ }^{\circ} \mathrm{C}$. The presence of several titanite generations supports this notion as the abundant titanite (+amphibole) is indicative of a slow cooling rate as discussed in the text. It can be further inferred from the static recrystallisation structures in D4affected rocks that the temperature remained elevated for a while after the pervasive phase of D4, although some gneisses within the SJSZ show features (feldspar microfracturing) that may reflect de- 
formation at $400-500{ }^{\circ} \mathrm{C}$ during the late- to postD4 period. The scarcity of retrograde alteration suggests that the temperature dropped relatively fast after D4; this is supported by the calculations of the exhumation rates. D3 and D4 were most intense within the SJSZ, although minor effects of D3 and/or early D4 can also be observed SW of the shear zone. During D4 ( $-1.79 \mathrm{Ga})$, the convergence in the study area was approximately $\mathrm{N}-\mathrm{S}$ to NNE-SSW directed, as opposed to the WNW-ESE directed compression resulting from the Nordic orogeny (Lahtinen et al., 2005); the difference in the direction of the convergence is allocated to a large-scale compartmentalisation of far-field stresses, also suggested in Torvela \& Ehlers (2010).

Most mylonites within the study area formed during D4 $(\sim 1.79 \mathrm{Ga})$, although some mylonites may have formed earlier. As concluded above, the rocks cooled rapidly and without extensive deformation after D4. Consequently, semi-brittle and brittle structures are rare within the study area. The rare pseudotachylytes that are observed were formed at relatively high crustal temperatures, possibly around $400{ }^{\circ} \mathrm{C}$.

\section{Acknowledgements}

We would like to thank Håkan Sjöström, Aulis Kärki and Karin Högdahl for their comments and suggestions at various stages of the project. Håkan Sjöström and Aulis Kärki also reviewed this manuscript, for which they have our sincere thanks. Juha Kauhanen prepared the thin sections. The work was partly financed by the National Graduate School in Geology, Stiftelsens för Åbo Akademi Forskningsinstitut and Sohlbergs Delegation.

\section{References}

Altenberger, U. \& Wilhelm, S., 2000. Ductile deformation of K-feldspar in dry eclogite facies shear zones in the Bergen Arcs, Norway. Tectonophysics 320, 107-121.

Bell, T.H., 1998. Recrystallization of biotite by subgrain rotation. In: Snoke, A., Tullis, J., Todd, V.R. (eds.) Fault related rocks - a photographic atlas. Princeton University Press, New Jersey, pp. 272-273.

Berger, A. \& Stünitz, H., 1996. Deformation mechanisms and reaction of hornblende: examples from the Bergell tonalite (Central Alps). Tectonophysics 257, 149-174.

Branigan, N.P., 1987. The role of shearing in the Proterozoic development of the Åland archipelago, S.W. Finland. Bulletin of the Geological Society of Finland 59, 117128.

Broska, I., Harlov, D., Tropper, P. \& Siman, P., 2007. Formation of magmatic titanite and titanite-ilmenite phase relations during granite alteration in the Tribeč Mountains, Western Carpathians, Slovakia. Lithos 95, 58-71.

DiToro, G. \& Pennacchioni, G., 2004. Superheated frictioninduced melts in zoned pseudotachylytes within the Adamello tonalites (Italian Southern Alps). Journal of Structural Geology 26, 1783-1801.

Edelman, N. \& Jaanus-Järkkälä, M., 1983. A plate tectonic interpretation of the Precambrian of the archipelago of southwestern Finland. Geological Survey of Finland, Bulletin 325, 4-33.

Ehlers, C. \& Ehlers, M., 1977. Shearing and multiple intrusion in the diabases of Åland archipelago, S.W. Finland. Geological Survey of Finland, Bulletin 289, 1-31.

Ehlers, C. \& Lindroos, A., 1990. Low-angle ductile shears in the early Proterozoic rock of SW Finland. Geologiska Föreningen i Stockholms Förhadlingar 112, 177-178.

Ehlers, C., Lindroos, A. \& Selonen, O., 1993. The late Svecofennian granite-migmatite zone of southern Finland - a belt of transpressive deformation and granite emplacement. Precambrian Research 64, 295-309.

Ehlers, C., Skiöld, T. \& Vaasjoki, M., 2004. Timing of Svecofennian crustal growth and collisional tectonics in Åland, SW Finland. Bulletin of the Geological Society of Finland 76, 63-91.

Evans, B.W., 1990. Phase relations in epidote-blueschists. Lithos 25, 3-23.

Evans, B., Renner, J. \& Hirth, G., 2001. A few remarks of the kinetics of static grain growth in rocks. International Journal of Earth Science 90, 88-103.

Gaál, G. \& Gorbatschev, R., 1987. An outline of the Precambrian evolution of the Baltic Shield. In: Gaál, G. \& Gorbatschev, R. (eds.) Precambrian Geology and Evolution of the Central Baltic Shield. Precambrian Research 35, $15-52$.

Gapais, D., 1989. Shear structures within deformed granites: mechanical and thermal indications. Geology 17, 11441147.

Hirth, G. \& Tullis, J. 1992. Dislocation creep regimes in quartz aggregates. Journal of Structural Geology 14, 145-159.

Högdahl, K., 2000. Late-orogenic, ductile shear zones and protolith ages in the Svecofennian Domain, central Sweden. Meddelanden från Stockholms Universitets Institution för Geologi och Geokemi 309. PhD Thesis, University of Stockholm, Sweden.

Högdahl, K., Sjöström, H. \& Bergman, S., 2009. Ductile shear zones related to crustal shortening and domain boundary evolution in the central Fennoscandian Shield. Tectonics 28, TC1003.

Hubbard, F. \& Branigan, N., 1987. Late Svecofennian mag- 
matism and tectonism, Åland, southwest Finland. In: Gaál, G. \& Gorbatschev, R. (eds.) Precambrian Geology and Evolution of the Central Baltic Shield. Precambrian Research 35, 241-256.

Imon, R., Okudaira, T. \& Fujimoto, A., 2002. Dissolution and precipitation processes in the deformed amphibolites: an example from the ductile shear zone of the Ryoke metamorphic belt, SW Japan. Journal of Metamorphic Geology 20, 297-308.

Jessell, M.W., 1987. Grain-boundary migration microstructures in a naturally deformed quartzite. Journal of Structural Geology 9, 1007-1014.

Johannes, W., Ehlers, C., Kriegsman, L.M. \& Mengel, K., 2003. The link between migmatites and S-type granites in the Turku area, southern Finland. Lithos 68, 69-90.

Kärki, A., Laajoki, K. \& Luukas, J., 1993. Major Palaeoproterozoic shear zones of the central Fennoscandian shield. Precambrian Research 64, 207-223.

Korhonen, J.V., Aaro, S., All, T., Nevanlinna, H., Skilbrei, J.R., Säävuori, H., Vaher, R., Zhdanova, L. \& Koistinen, T., 2002. Magnetic anomaly map of the Fennoscandian Shield 1:2 000 000. Geological Survey of Finland, Geological Survey of Norway, Geological Survey of Sweden, Ministry of Natural Resources of Russia.

Korja, A. \& Heikkinen, P., 2005. The accretionary Svecofennian orogen - insight from the BABEL profiles. Precambrian Research 136, 241-268.

Korsman, K., Koistinen, T., Kohonen, J., Wennerström, M., Ekdahl, E., Honkamo, M., Idman, H. \& Pekkala, Y. (eds.) Bedrock Map of Finland 1:1000000. Geological Survey of Finland.

Kruhl, J.H., 1996. Prism- and basal-plane parallel subgrain boundaries in quartz: a microstructural geothermobarometer. Journal of Metamorphic Geology 14, 581-589.

Kurhila, M., Vaasjoki, M., Mänttäri, I., Rämö, T. \& Nironen, M., 2005. U-Pb ages and $\mathrm{Nd}$ isotope characteristics of the lateorogenic, migmatizing microcline granites in southwestern Finland. Bulletin of the Geological Society of Finland 77, 105-128.

Lahtinen, R., Korja, A. \& Nironen, M., 2005. Palaeoproterozoic tectonic evolution. In: Lehtinen, M., Nurmi, P.A. \& Rämö, O.T. (eds.) Precambrian Geology of Finland - Key to the Evolution of the Fennoscandian Shield. Developments in Precambrian Geology 14, 481-532.

Laird, J., 1980. Phase equilibria in mafic schist from Vermont. Journal of Petrology 21, 1-37.

Levin, T., Engström, J., Lindroos, A., Baltybaev, S. \& Levchenkov, O., 2005. Late-Svecofennian transpressive deformation in SW Finland - evidence from late-stage D3 structures. Geologiska Föreningen i Stockholms Förhadlingar 127, 129-137

Lin, A., 1994. Glassy pseudotachylyte veins from the Furyn fault zone, northwest China. Journal of Structural Geology $16,71-84$.
Lin, A. \& Shimamoto, T., 1998. Selective melting processes as inferred from experimentally generated pseudotachylytes. Journal of Asian Earth Science 16, 533-545.

Liou, J.G., Kuniyoshi, S. \& Ito, K., 1974. Experimental studies of the pure phase relation between greenschist and amphibolite in a basaltic system. American Journal of Science 274, 613-632.

Mainprice, D., Bouchez, J.L., Blumenfeld, B. \& Tubia, J.M., 1986. Dominant c-slip in naturally deformed quartz: implications for dramatic plastic softening at high temperature. Geology 14, 819-822.

McNulty, B.A., 1995. Pseudotachylyte generated in the semibrittle and brittle regimes, Bench Canyon shear zone, central Sierra Nevada. Journal of Structural Geology 17, 15071521.

Moody, J.B., Meyer, D., Jenkins, J.E., 1982. Experimental characterization of the greenschist/amphibolite boundary in mafic systems. American Journal of Science 283, 48-92.

Nironen, M., 1997. The Svecofennian orogen: a tectonic model. Precambrian Research 86, 21-44.

O'Hara, K.D., 2001. A pseudotachylyte geothermometer. Journal of Structural Geology 23, 1345-1357.

Olsen, T.S. \& Kohlstedt, D.L., 1985. Natural deformation and recrystallisation of some intermediate plagioclase feldspars. Tectonophysics 111, 107-131.

Passchier, C.W. \& Trouw, R.A.J., 2005. Microtectonics. Springer-Verlag. 366 p.

Patchett, J. \& Kouvo, O., 1986. Origin of continental crust of 1.9-1.7 Ga age: $\mathrm{Nd}$ isotopes and $\mathrm{U}-\mathrm{Pb}$ zircon ages in the Svecokarelian terrain of South Finland. Contributions to Mineralogy and Petrology 92, 1-12

Pennacchioni, G. \& Cesare, B., 1997. Ductile-brittle transition in pre-Alpine amphibolite facies mylonites during evolution from water-present to water-deficient conditions (Mont Mary nappe, Italian Western Alps). Journal of Metamorphic Geology 15, 777-791.

Pryer, L.L., 1993. Microstructures in feldspars from a major crustal thrust zone: the Grenville Front, Ontario, Canada. Journal of Structural Geology 15, 21-36.

Pryer, L.L., \& Robin, P.Y.F., 1995. Retrograde metamorphic reactions in deforming granites and the origin of flame perthites. Journal of Metamorphic Geology 14, 645-658.

Sjöström, H. \& Bergman, S., 1998. Svecofennian Metamorphic and Tectonic Evolution of East Central Sweden. Research report of a project entitled: Svekofennisk metamorf och tektonisk utveckling i östra mellansverige. Research report, Geological Survey of Sweden, $42 \mathrm{p}$.

Soesoo, A., Puura, V., Kirs, J., Petersell, V., Niin, M. \& All, T., 2004. Outlines of the Precambrian basement of Estonia. Proceedings of the Estonian Academy of Sciences, Geology 53/3, 149-164.

Stålfors, T. \& Ehlers. C., 2005. Emplacement mechanisms of late-orogenic granites: structural and geochemical evidence from southern Finland. International Journal of Earth 
Sciences 95, 557-568.

Scholz, C.H., 1988. The brittle-plastic transition and the depth of seismic faulting. Geologische Rundschau 77, 319-328.

Stipp, M., Stünitz, H., Heilbronner, R. \& Schmid, S.M., 2002.

The eastern Tonale fault zone: a "natural laboratory" for crystal plastic deformation of quartz over a temperature range from 250 to $700^{\circ} \mathrm{C}$. Journal of Structural Geology 24, 1861-1884.

Suominen, V., 1991. The chronostratigraphy of southwester Finland with special reference to Postjotnian and Subjotnian diabases. Geological Survey of Finland, Bulletin 356, $1-100$.

Torvela, T., 2007. The Sottunga-Jurmo shear zone: Structure and deformation History of a Crustal-Scale Ductile Shear Zone in SW Finland. Acta Academiae Aboensis 67/1. PhD Thesis, Åbo Akademi University, Finland. 187 pp.

Torvela, T. \& Annersten, H., 2005. PT-conditions of deformation within the Palaeoproterozoic South Finland shear zone: some geothermobarometric results. Bulletin of the Geological Society of Finland 77, 151-164.

Torvela, T. \& Ehlers, C., 2010. From ductile to brittle deformation - the structural development of and strain distribution along a crustal-scale shear zone in SW Finland. International Journal of Earth Sciences 99, 11331152.

Torvela, T., Mänttäri, I. \& Hermansson, T., 2008. Timing of deformation phases within the South Finland shear zone, SW Finland. Precambrian Research 160, 277-298.

Tullis, J.A. \& Yund, R.A., 1987. Transition from cataclastic flow to dislocation creep of feldspar: mechanisms and microstructures. Geology 15, 606-609.

Tullis, J.A. \& Yund, R.A., 1991. Diffusion creep in feldspar aggregates: experimental evidence. Journal of Structural Geology 13, 987-1000.
Väisänen, M., 2002. Tectonic Evolution of the Palaeoproterozoic Svecofennian Orogen in Southwestern Finland. Annales Universitatis Turkuensis, AII 154. PhD Thesis, University of Turku, Finland. 143 pp.

Väisänen, M. \& Hölttä, P., 1999. Structural and metamorphic evolution of the Turku migmatite complex, southwestern Finland. Bulletin of the Geological Society of Finland 71, 177-218.

Väisänen, M. \& Mänttäri, I., 2002. 1.90-1.88 Ga primitive arc, mature arc and back-arc basin in the Orijärvi area, SW Finland. Bulletin of the Geological Society of Finland 74, 185-214.

Väisänen, M., Mänttäri, I., Kriegsman, L. M. \& Hölttä, P., 2000. Tectonic setting of post-collisional magmatism in the Palaeoproterozoic Svecofennian orogen, SW Finland. Lithos 54, 63-81.

Vidal, J.L., Kubin, L., Debat, P. \& Soula, J.L., 1980. Deformation and dynamic recrystallisation of K-feldspar augen in orthogneiss from Montagne Noir, Occitania. Lithos 13, 247-257.

Welin, E., Vaasjoki, M. \& Suominen, V., 1983. Age differences between $\mathrm{Rb}-\mathrm{Sr}$ whole rock and U-Pb zircon ages of syn- and postorogenic Svecokarelian granitoids in Sottunga, SW Finland. Lithos 16, 297-305.

White, S.H., Burrows, S.E., Carreras, J., Shaw, N.D. \& Humphreys, F.J., 1980. On mylonites in ductile shear zones. Journal of Structural Geology 2, 175-187.

Xirouchakis, D., Lindsley, D.H. \& Frost, R., 2001. Assemblages with titanite $\left(\mathrm{CaTiSiO}_{4}\right), \mathrm{Ca}-\mathrm{Mg}-\mathrm{Fe}$ olivine and pyroxenes, Fe-Mg-Ti oxides, and quartz: Part II, Application. American Mineralogist 86, 254-264. 